\title{
Placenta-derived exosomes continuously increase in maternal circulation over the first trimester of pregnancy
}

Suchismita Sarker ${ }^{1}$, Katherin Scholz-Romero ${ }^{1}$, Alejandra Perez ${ }^{2}$, Sebastian E Illanes ${ }^{1,2,3}$, Murray D Mitchell ${ }^{1}$, Gregory E Rice ${ }^{1,2}$ and Carlos Salomon ${ }^{1,2^{*}}$

\begin{abstract}
Background: Human placenta releases specific nanovesicles (i.e. exosomes) into the maternal circulation during pregnancy, however, the presence of placenta-derived exosomes in maternal blood during early pregnancy remains to be established. The aim of this study was to characterise gestational age related changes in the concentration of placenta-derived exosomes during the first trimester of pregnancy (i.e. from 6 to 12 weeks) in plasma from women with normal pregnancies.

Methods: A time-series experimental design was used to establish pregnancy-associated changes in maternal plasma exosome concentrations during the first trimester. A series of plasma were collected from normal healthy women (10 patients) at $6,7,8,9,10,11$ and 12 weeks of gestation $(n=70)$. We measured the stability of these vesicles by quantifying and observing their protein and miRNA contents after the freeze/thawing processes. Exosomes were isolated by differential and buoyant density centrifugation using a sucrose continuous gradient and characterised by their size distribution and morphology using the nanoparticles tracking analysis (NTA; Nanosight ${ }^{\mathrm{TM}}$ ) and electron microscopy (EM), respectively. The total number of exosomes and placenta-derived exosomes were determined by quantifying the immunoreactive exosomal marker, CD63 and a placenta-specific marker (Placental Alkaline Phosphatase PLAP).
\end{abstract}

Results: These nanoparticles are extraordinarily stable. There is no significant decline in their yield with the freeze/ thawing processes or change in their EM morphology. NTA identified the presence of 50-150 nm spherical vesicles in maternal plasma as early as 6 weeks of pregnancy. The number of exosomes in maternal circulation increased significantly (ANOVA, $p=0.002$ ) with the progression of pregnancy (from 6 to 12 weeks). The concentration of placentaderived exosomes in maternal plasma (i.e. PLAP ${ }^{+}$) increased progressively with gestational age, from 6 weeks $70.6 \pm$ $5.7 \mathrm{pg} / \mathrm{ml}$ to 12 weeks $117.5 \pm 13.4 \mathrm{pg} / \mathrm{ml}$. Regression analysis showed that weeks is a factor that explains for $>70 \%$ of the observed variation in plasma exosomal PLAP concentration while the total exosome number only explains 20\%.

Conclusions: During normal healthy pregnancy, the number of exosomes present in the maternal plasma increased significantly with gestational age across the first trimester of pregnancy. This study is a baseline that provides an ideal starting point for developing early detection method for women who subsequently develop pregnancy complications, clinically detected during the second trimester. Early detection of women at risk of pregnancy complications would provide an opportunity to develop and evaluate appropriate intervention strategies to limit acute adverse sequel.

Keywords: Exosomes, Pregnancy, Placenta, Fetal-maternal exchange

\footnotetext{
* Correspondence: c.salomongallo@uq.edu.au

${ }^{1} \cup \mathrm{Q}$ Centre for Clinical Research, Centre for Clinical Diagnostics, Royal

Brisbane and Women's Hospital, University of Queensland, Building 71/918,

Herston QLD 4029, Queensland, Australia

${ }^{2}$ Department of Obstetrics and Gynaecology, Faculty of Medicine,

Universidad de los Andes, Santiago, Chile

Full list of author information is available at the end of the article
} 


\section{Background}

The placenta plays a pivotal role in mediating maternal adaptation to pregnancy as well as regulating fetal growth and development. Pregnancy-induced changes are affected by the release of soluble autacoids as early as 6 to 8 weeks of gestation $[1,2]$ and the invasion of placental cells into the maternal tissues to modify maternal immune, cardiovascular and metabolic activities. Recently, we and others [3-7] have identified an additional pathway by which the placenta communicates with the maternal system to induce changes during pregnancyplacental exosomal signalling.

Exosomes are bilipid membrane-bound nanovesicles (50-120 nm diameter) that are actively released (via exocytosis) from cells into the extracellular space and body fluids under physiological and pathophysiological conditions [8]. Their molecular cargo of proteins, microRNAs, mRNAs and lipids appear to be selectively packaged by the late endosomal system to regulate the phenotype of target cells $[3,4,6]$. Recent studies have highlighted the putative utility of tissue-specific nanovesicles (e.g. exosomes) in the diagnosis of disease onset and treatment monitoring $[4,9,10]$.

Previously, we have established that placental cells release exosomes in response to changes in the extracellular milieu (including oxygen tension and glucose concentration) and that placental cell-derived exosomes regulate target cell migration and invasion $[3,4]$. In addition, we have identified placental-derived exosomes in maternal blood and reported that the concentration of placental exosomes in the maternal blood increases during normal, healthy pregnancy [7]. During early placentation, the cytotrophoblast cells form a highly invasive extravillous trophoblast that can migrate into the decidua and invade the first third of the myometrium, inducing remodelling of spiral arterioles to produce low-resistance vascular system, essential for fetal development [11]. The relative reduction of utero-placental flow caused by abnormal placentation triggers the development of placental originated diseases such as preeclampsia. Available data suggest that the concentrations of placental-derived exosomes in the maternal blood could be a potential marker of abnormal placentation [12,13].

Early detection of disease risk and onset is the first step in implementing efficacious treatment and improving patient outcome. To date, the concentration profile of placentaderived exosomes in the maternal blood during first trimester has not been established. Until this profile is defined, the utility of placental exosomes as an early biomarker for placental dysfunction will remain equivocal. In this study, therefore, a time-series experimental design was used to test the hypothesis that the concentration of placental exosomes in the maternal plasma of normal healthy women changes during the early pregnancy state (i.e. 6-12 weeks).

\section{Methods}

\section{Patient selection and sample collection}

A time-series experimental design was used to establish the variation in plasma exosome characteristics during normal pregnancy. All experimental procedures were conducted within an ISO17025 accredited (National Association of Testing Authorities, Australia) research facility. All data were recorded within a 21 CERF part 11 compliant electronic laboratory notebook (Iris note, Redwood City, CA, USA). Plasma samples were collected from 10 women during their first trimester of pregnancy. All patients were enrolled with informed consent and underwent routine obstetrical care at the Hospital Parroquial de San Bernardo (Santiago, Chile). Estimation of gestational age was made based on the first day of their last menstrual period and confirmed by transvaginal ultrasound at the recruitment (i.e. 6 weeks). Each patient, gave consent to have weekly blood sample collection between 6 and 12 weeks of gestation $(n=70,10$ patients with weekly blood collection at $6,7,8,9,10,11$ and 12 weeks of pregnancy). The protocol of the study was approved by the Institutional Review Board of the Universidad de los Andes (Santiago, Chile). Obstetrical history and physical findings were recorded regarding previous spontaneous abortions, course of previous pregnancies, hypertension, gestational diabetes and preeclampsia. Peripheral venous blood samples were collected in EDTA treated tubes (BD Vacutainer ${ }^{\oplus}$ Plus plastic plasma tube) from which plasma samples were obtained by centrifugation at $2000 \times \mathrm{g}$ at $4^{\circ} \mathrm{C}$ for $10 \mathrm{~min}$. The plasma samples were stored in aliquots at $-80^{\circ} \mathrm{C}$ until analysed (not more than three months).

\section{Exosome isolation}

Exosomes were isolated as previously described $[3,4,7,14]$. Briefly, plasma from each patient was utilised to isolate exosomes. Plasma $(2.5 \mathrm{ml})$ was diluted with equal volume of PBS ( $\mathrm{pH}$ 7.4) and exosomes were isolated through differential centrifugation, microfiltration and buoyant density ultracentrifugation. Centrifugation was initially performed at $2,000 \times \mathrm{g}$ at $4^{\circ} \mathrm{C}$ for $30 \mathrm{~min}$ (Thermo Fisher Scientific Ins., Asheville, NC, USA, Sorvall ${ }^{\circ}$, high speed microcentrifuge, fixed rotor angle: $90^{\circ}$ ) followed by $12,000 \times$ g at $4^{\circ} \mathrm{C}$ for $45 \mathrm{~min}$ to sediment cell nuclei, mitochondria and debris. The supernatant fluid $(\sim 5 \mathrm{ml})$ was transferred to an ultracentrifuge tube (Ultracrimp tubes, Thermo Fisher Scientific Ins., Asheville, NC, USA) and was centrifuged at $200,000 \times \mathrm{g}$ at $4^{\circ} \mathrm{C}$ for $2 \mathrm{~h}$ (Thermo Fisher Scientific Ins., Asheville, NC, USA, Sorvall ${ }^{\oplus}, \mathrm{T}-8100$, fixed angle ultracentrifuge rotor). The pellet was suspended in PBS $(5 \mathrm{ml})$ and filtered through a $0.22 \mu \mathrm{m}$ filter (SteritopTM, Millipore, Billerica, MA, USA). The filtrate was centrifuged at $200,000 \times \mathrm{g}$ at $4^{\circ} \mathrm{C}$ for $70 \mathrm{~min}$ (Thermo Fisher Scientific 
Ins., Asheville, NC, USA, Sorvall ${ }^{\circ}, \mathrm{T}-8100$, fixed angle ultracentrifuge rotor) and the pellet resuspended in $2.5 \mathrm{M}$ sucrose $(4 \mathrm{ml})$.

Purification of exosomes using a continuous sucrose gradient The resuspended 200,000 g pellet in 2.5 M sucrose was added at the bottom of an ultracentrifuge tube. A continuous sucrose gradient (26 ml; 0.25-2.5 M) was made above $4 \mathrm{ml}$ of exosome suspension using a Hoefer SG30 gradient maker (GE Healthcare, NSW, Australia) and centrifuged at 110,000 g for $20 \mathrm{~h}$ (Sorvall, SureSpin ${ }^{\mathrm{Tm}}$ 630/360, SwingingBucket ultracentrifuge rotor). Fractions (10 in total, $3 \mathrm{ml}$ each) were collected automatically using a Pulse-Free Flow Peristaltic Pump with a flow rate range of $3 \mathrm{ml}$ per min (GILSON Miniplus ${ }^{\oplus}$ model 3 ) and the Fraction Collector (GILSON FC 203B model). The density of each fraction was determined using the refraction index with OPTi digital refractometer (Bellingham + Stanley Inc., Lawrenceville, GA, USA). The coefficient of variation (CV) was less than $8 \%$ for the density of each fraction. Fractions ( $3 \mathrm{ml} \mathrm{each})$ were diluted in PBS $(60 \mathrm{ml})$ and then centrifuged at 200,000 $\times \mathrm{g}$ for $70 \mathrm{~min}$. The $200,000 \mathrm{~g}$ pellet was resuspended in $50 \mu \mathrm{l} \mathrm{PBS}$ and stored at $-80^{\circ} \mathrm{C}$. Exosomal protein concentrations were determined by a colorimetric assay (DC ${ }^{\mathrm{rm}}$ Protein Assay, Bio-Rad Laboratories, Hercules, CA, USA) [4].

\section{Identification of nanoparticles by nanoparticle tracking analysis (NTA)}

NTA measurements were performed using a NanoSight NS500 instrument (NanoSight NTA 2.3 Nanoparticle Tracking and Analysis Release Version Build 0033) following the manufacturer's instructions. The NanoSight NS500 instrument measured the rate of Brownian motion of nanoparticles in a light scattering system that provides a reproducible platform for specific and general nanoparticle characterization (NanoSight Ltd., Amesbury, United Kingdom). Samples were processed in duplicates and diluted with PBS over a range of concentrations to obtain between 10 and 100 particles per image (optimal $~ 50$ particles $\mathrm{x}$ image) before analysing with NTA system. The samples were mixed before introducting into the chamber (temperature: $25^{\circ} \mathrm{C}$ and viscosity: $0.89 \mathrm{cP}$ ) and the camera level set to obtain image that has sufficient contrast to clearly identify particles while minimizing background noise a video recording (camera level: 10 and capture duration: $60 \mathrm{~s}$ ). The captured videos ( 2 videos per sample) were then processed and analysed. A combination of high shutter speed (450) and gain (250) followed by manual focusing enabled optimum visualization of a maximum number of vesicles. We included a minimum of 200 tracks completed per video in duplicates. NTA post acquisition settings were optimized and kept constant between samples (Frames Processed: 1496 of 1496, Frames per Second:
30, camera shutter: $20 \mathrm{~ms}$; Calibration: $139 \mathrm{~nm} /$ pixel, Blur: $3 \times 3$; Detection Threshold: 10; Min Track Length: Auto; Min Expected Size: Auto), and each video was then analyzed to give the mean, mode, and median particles size together with an estimate of the number of particles. An Excel spreadsheet (Microsoft Corp., Redmond, Washington) was also automatically generated, showing the concentration at each particle size.

\section{Transmission electron microscopy (TEM)}

For the TEM analysis, exosome pellets (as described above, $30 \mu \mathrm{g}$ protein) were fixed in $3 \%(\mathrm{w} / \mathrm{v})$ glutaraldehyde and $2 \%$ paraformaldehyde in cacodylate buffer, $\mathrm{pH}$ 7.3. Exosome samples were then applied to a continuous carbon grid and negatively stained with $2 \%$ uranyl acetate. The samples were examined in an FEI Tecnai 12 transmission electron microscope (FEI ${ }^{\mathrm{mm}}$, Hillsboro, Oregon, USA) in the Central Analytical Research Facility, Institute for Future Environments, Queensland University of Technology (QUT) (see Acknowledgements).

\section{Quantification of placental cell-derived exosome}

The concentration of exosomes in maternal circulation was expressed as the total immunoreactive exosomal CD63 (ExoELISA ${ }^{\mathrm{Tm}}$, System Biosciences, Mountain View, CA). Briefly, $10 \mu \mathrm{g}$ of exosomal protein was immobilised in 96-well microtiter plates and incubated overnight (binding step). Plates were washed three times for $5 \mathrm{~min}$ using a wash buffer solution and then incubated with exosome specific primary antibody (CD63) at room temperature (RT) for $1 \mathrm{~h}$ under agitation. Plates were washed and incubated with secondary antibody (1:5000) at RT $1 \mathrm{~h}$ under agitation. Plates were washed and incubated with Super-sensitive TMB ELISA substrate at RT for 45 min under agitation. The reaction was terminated using Stop Buffer solution. Absorbance was measured at $450 \mathrm{~nm}$. The number of exosomes/ml, (ExoELISA ${ }^{\mathrm{Tm}} \mathrm{kit}$ ) was obtained using an exosomal CD63 standard curve calibrated against nanoparticle tracking data (i.e. number of exosomes, NanoSight ${ }^{\mathrm{TM}}$ ).

For placental cell-derived exosomes, the concentration of exosomal PLAP was quantified using a commercial ELISA kit (MYBioSource MBS701995, San Diego, CA, USA) according to manufacturer's instructions (detection range: 84-2000 pg/ml; sensitivity: 34 pg/ml; intra-assay precision within an assay: $\mathrm{CV} \%<10 \%$; inter-assay between assays: CV\% $<15 \%)$ Briefly, $10 \mu$ g of exosomal protein was added to each well of a 96-well microtitre plate and incubated at $37^{\circ} \mathrm{C}$ for $30 \mathrm{~min}$. Plates were washed three times while shaking for $20 \mathrm{~s}$ and $50 \mu \mathrm{l}$ of HRP-conjugate was added to each well and incubated at $37^{\circ} \mathrm{C}$ for $20 \mathrm{~min}$. Plates were washed and incubated with $50 \mu \mathrm{l}$ of substrate $A$ and $50 \mu$ l of substrate $B$ at $37^{\circ} \mathrm{C}$ for $15 \mathrm{~min}$. The incubation was terminated using $50 \mu \mathrm{l}$ of stop 
solution at RT for 2 min under agitation. Absorbance was measured at $450 \mathrm{~nm}$. Exosomal PLAP was expressed as pg PLAP /ml plasma.

\section{Stability of the exosomal quantification}

To determine the stability of the exosomes during freezethaw cycles, fresh plasma $(5.0 \mathrm{ml})$ from healthy women were obtained and divided into two $2.5 \mathrm{ml}$ samples (A and B). Exosomes were immediately isolated from the first aliquot (A: fresh plasma) by differential and buoyant density centrifugation and then characterised by the number of exosome particles using an ELISA kit (ExoELISA ${ }^{\mathrm{Tm}}$, System Biosciences, Mountain View, CA), morphologically by electron microscope, microRNA content by real time PCR and protein profiling by mass-spectrometry. Sample $\mathrm{B}$ plasma was stored at $-80^{\circ} \mathrm{C}$ for 2 months (B: frozen plasma), prior to exosome isolation and characterisation. miRNA isolation: miRNA were isolated from exosome particles as we have previously described [14]. Ambion mirVana PARIS Kit (Invitrogen, USA) was used to extract exosomal total RNA from fresh and frozen plasma by following the manufacturer's procedure. Exosomes were first lysed by adding cell disruption buffer and vortexed or pipetted vigorously. Denaturing solution was added to samples and incubated on ice for $5 \mathrm{~min}$. The first two steps stabilize RNA and inactivate RNases. The lysate is then subjected to Acid-Phenol:Chloroform extraction by adding Acid-Phenol:Chloroform, vortexed and centrifuged at $10,000 \times \mathrm{g}$ for $5 \mathrm{~min}$. Recovery of the aqueous phase obtains semi-pure RNA samples, removing most of the other cellular components. $100 \%$ ethanol was mixed and passed through a filter cartilage. The filter was washed three times and the RNA was eluted with nuclease-free water. Real-time PCR: Reverse transcription was performed using the miScript Reverse Transcription Kit (QIAGEN, Valencia, CA, USA) in a total volume of $20 \mu \mathrm{l}$. cDNA was synthesised from the maximum volume of exosomal RNA $(12 \mu \mathrm{l})$ using the BIO-RAD $\mathrm{T}^{100^{\text {тм }}}$ Thermal Cycler (USA) running for $60 \mathrm{~min}$ at $37^{\circ} \mathrm{C}, 5 \mathrm{~min}$ for $95^{\circ} \mathrm{C}$ and $60 \mathrm{~min}$ for $37^{\circ} \mathrm{C}$. As the control, RNase-free water was added as the RNA template. Real-time PCR was performed with miScript SYBR Green Kit (QIAGEN, Valencia, CA, USA). Forward primers (miScript primer assays, QIAGEN, Valencia, CA, USA) designed to detect the housekeeping gene, human RNU6-2 (RNU6B) was used. The reactions were performed in triplicate using the BIO-RAD $\mathrm{iQ}^{\text {rm}} 5$ Multicolor Real-Time PCR Detection System (USA) with the following conditions: $94^{\circ} \mathrm{C}$ for $3 \mathrm{~min}, 35$ amplification cycles of $94^{\circ} \mathrm{C}$ for $45 \mathrm{~s}$, $55^{\circ} \mathrm{C}$ for $30 \mathrm{~s}$ and $72^{\circ} \mathrm{C}$ for $30 \mathrm{~s}, 72^{\circ} \mathrm{C}$ for $10 \mathrm{~min}, 12^{\circ} \mathrm{C}$ for $\infty$ min. Proteomic analysis of exosomes by mass spectrometry (MS): We utilised a Liquid Chromatography (LC) and Mass Spectrometry (MS) LC/MS/MS instrumentation available within the University of Queensland
Centre for Clinical Research (5500qTRAP and 5600 Triple TOF) to undertake in depth quantitative proteomic analysis of the exosome samples (isolated from fresh and frozen plasma) to determine the proteome of exosomes as we have previously published [4]. Briefly, exosomes were adjusted to $8 \mathrm{M}$ urea in $50 \mathrm{mM}$ ammonium bicarbonate, $\mathrm{pH} 8.5$, and reduced with tris (2-carboxyethyl) phosphine $(5 \mathrm{mM})$ at room temperature for $1 \mathrm{~h}$. Proteins were then alkylated in $10 \mathrm{mM}$ IAA for $1 \mathrm{~h}$ in the dark. The sample was diluted 1:10 with $50 \mathrm{mM}$ ammonium bicarbonate and then digested with trypsin $(20 \mu \mathrm{g})$ at $37^{\circ} \mathrm{C}$ for $18 \mathrm{~h}$. The samples were dried by centrifugal evaporation to remove the acetonitrile and then redissolved in Solvent A. The digested protein samples were analysed using a 5600 Triple TOF mass spectrometer (ABSciex) to obtain initial high mass accuracy survey MS/ MS data, identifing the peptides present in the samples. The in depth proteomic analysis was performed using the Information Dependent Acquisition (IDA) experiments on the 5600 Triple TOF MS and utilized an enhanced MS survey scan (m/z350-1500) followed by 50 data-dependent product ion scans of the 50 most intense precursor ions. The MS data was analysed with the Markerview software package using Principal Components Analysis (PCA) or PCA-Discriminate Analysis (PCA-DA) which compares data across multiple samples, groupings the data sets, and graphically showing the groups in a Scores plot. The Loadings plot provides valuable insight into variables that lead to sample clustering and illustrates which biomarkers are up- or down-regulated. All mass spectra were analysed using the Mascot and Protein Pilot search engines against the Swissprot-swissprot database with the species set as human (scores greater than 30). False discovery rate (FDR) was estimated using a reversed sequence database. Finally, proteins identified were submitted to bioinformatic pathway analysis (Ingenuity Pathway Analysis [IPA]; Ingenuity Systems, Mountain View, CA; www.ingenuity.com).

\section{Statistical analysis}

Data are presented as mean \pm SEM, with $\mathrm{n}=10$ different patients per group (i.e. 6, 7, 8, 9, 10, 11, 12 weeks). The effect of gestational age on number of exosome particles and placental-derived exosomes were assessed by two-way ANOVA, with variance partitioned between gestational age and subject. Statistical difference between group means was assessed by Dunn's test to compare each treatment to the control group where the data distribution approximates normality and by Mann-Whitney U-test for distribution independent data analysis. Two group means were statistically assessed by Student's t-test. Statistical significance was defined as $\mathrm{p}<0.05$. 


\section{Results}

\section{Exosome characterisation}

Maternal plasma exosomes isolated by differential and sucrose density gradient centrifugation were characterised by a buoyant density of 1.122 to $1.197 \mathrm{~g} / \mathrm{ml}$ (fractions 4 to 7 ) (Figure 1A-D). Nanoparticle tracking analysis showed a particle size distribution of 200,000 $\times$ g pellet (Figure $1 \mathrm{~A}$ ) ranging from 30 to $300 \mathrm{~nm}$ in diameter corresponding to microsomal fraction (including exosomes particles) with an average of $147 \pm 71 \mathrm{~nm}$ (mean \pm SD) (Figure 1B). After the sucrose continuous gradient, we mixed the enriched exosomal fractions (1.122 to $1.197 \mathrm{~g} / \mathrm{ml}$ ) (Figure 1C) and obtained a particle size distribution ranged from 50 to $140 \mathrm{~nm}$ in diameter, with an average of $98 \pm 39 \mathrm{~nm}$ (mean $\pm \mathrm{SD}$ ) (Figure 1D). Electron microscopy revealed the presence of spherical vesicles, with a typical cup-shape and diameters ranging from 30 to $120 \mathrm{~nm}$ (Figure 1D, insert).

The stability of exosomes after a freeze and thaw cycle was evaluated using fresh and frozen plasma. No significant difference was observed using fresh or frozen plasma in exosome quantification, exosomal marker expression, microRNA expression or protein content (Figure 2A-D, Table 1).

\section{Placenta-derived exosome increased during first trimester in normal pregnancy}

Pooled exosome-containing fractions (i.e. fractions 4 to 7) were further characterised by determining the number of exosome (NEP) and exosomal PLAP concentration in the serial samples of maternal plasma obtained during first trimester of pregnancy (i.e. 6-12 weeks).

The gestational age variation in plasma exosome number was analysed by two-way ANOVA with the variance partitioned between gestational age and subject. A significantly effect of gestational age was identified $(n=69$, one missing value, $\mathrm{p}<0.005)$. A post-hoc multiple range test was used to identify statistically significant $(p<0.05)$ differences between pairwise comparisons (Figure 3A). In addition, a significant effect of subject was identified ( $n=69$, one missing value, $\mathrm{p}<0.05$ ) (Figure $3 \mathrm{~B}$ ). In addition, NEP and gestational age (i.e. 6-12 weeks) displayed a significant positive linear relationship $\left(\mathrm{r}^{2}=0.202, \mathrm{p}<0.001, \mathrm{n}=69\right.$, one missing value).

To assess gestational variation in placenta-derived exosomes, exosomal immunoreative (IR) PLAP was quantified using a commercial ELISA kit (see Methods). IR exosomal PLAP concentrations were analysed by two-way ANOVA with the variance partitioned between gestational age and subject. A significant effect of gestational age was identified $(\mathrm{p}<0.0001, \mathrm{n}=69$, one missing value) (Figure $3 \mathrm{C}$ ). A post-hoc multiple range test was used to identify statistically significant $(\mathrm{p}<0.05)$ differences between pairwise comparisons (Figure 3D). No significant effect of patient on exosomal PLAP concentration was identified $(\mathrm{p}=0.123)$. Immunoreactive exosomal PLAP concentration and gestational age displayed a significant positive linear linear relationship $\left(\mathrm{r}^{2}=0.711, \mathrm{p}<0.001, \mathrm{n}=69\right.$, one missing value).

\section{Specific placental-derived exosomes}

Exosomal PLAP concentration and exosome number were subjected to linear regression analysis. The fitted linear model was described by the following equation: plasma exosomal PLAP $\mathrm{pg} / \mathrm{ml}=85.6+5.47 \times 10^{-11} \times$ exosome number $/ \mathrm{ml}(\mathrm{p}<0.006, \mathrm{n}=69$, one missing pair). The coefficient of determination $\left(\mathrm{r}^{2}\right)$ was 10.8 (Figure $4 \mathrm{~A}$ ).

To estimate changes in the relative contribution of placental exosomes within the total exosomes present in maternal plasma and identify changes over the gestational age, the apparent PLAP content per $10^{9}$ exosome (PLAP ratio) was determined. Overall PLAP ratio averaged $2.01 \pm 0.33 \times 10^{-9}$ exosomal PLAP $(\mathrm{pg})$ per exosome. The effects of gestational age on PLAP ratio were assessed by Kruskal-Wallis one-way ANOVA. No significant effect of gestational age on PLAP ratio was identified $(p=0.06)$ (Figure 4B).

\section{Discussion}

Currently, there are no proven means of identifying presymptomatic women who subsequently develop complications of pregnancy during early pregnancy. Most women who are triaged into high-risk clinical units based on previous poor obstetric history ultimately have uncomplicated pregnancies. Available evidence supports the hypothesis that the aetiology of pregnancy complications begins during 1 st trimester $[15,16]$. If this is the case, profile of placenta-derived biomarkers during early pregnancy may be common between women with risk of developing pregnancy complications. Identification of such characteristics would provide opportunity to develop clinically useful early pregnancy screening tests.

Previously we have established that normal pregnancy is associated with the increase of exosomes into maternal plasma and the concentration of placenta-derived exosomes increases by 6 -fold in uncomplicated healthy pregnancy during the first to third trimester [7] , however, the exosome profile in early pregnancy (i.e. from 6 to 12 weeks) remained to be established. The aim of this study was to characterise placenta-derived exosomes in maternal plasma over the first trimester of pregnancy and observe inter-subject variations in the exosome concentration. Weekly collected blood samples (from 6 to 12 weeks) were collected from normal healthy women to isolate and characterise the exosomes. The presence of exosomes were confirmed by: size (50-120 nM), and buoyant density (1.122- $1.197 \mathrm{~g} / \mathrm{ml}$ ). Endosomal (CD63) and placental (PLAP) antigens were identified in maternal plasma from as early as sixth week of pregnancy. 


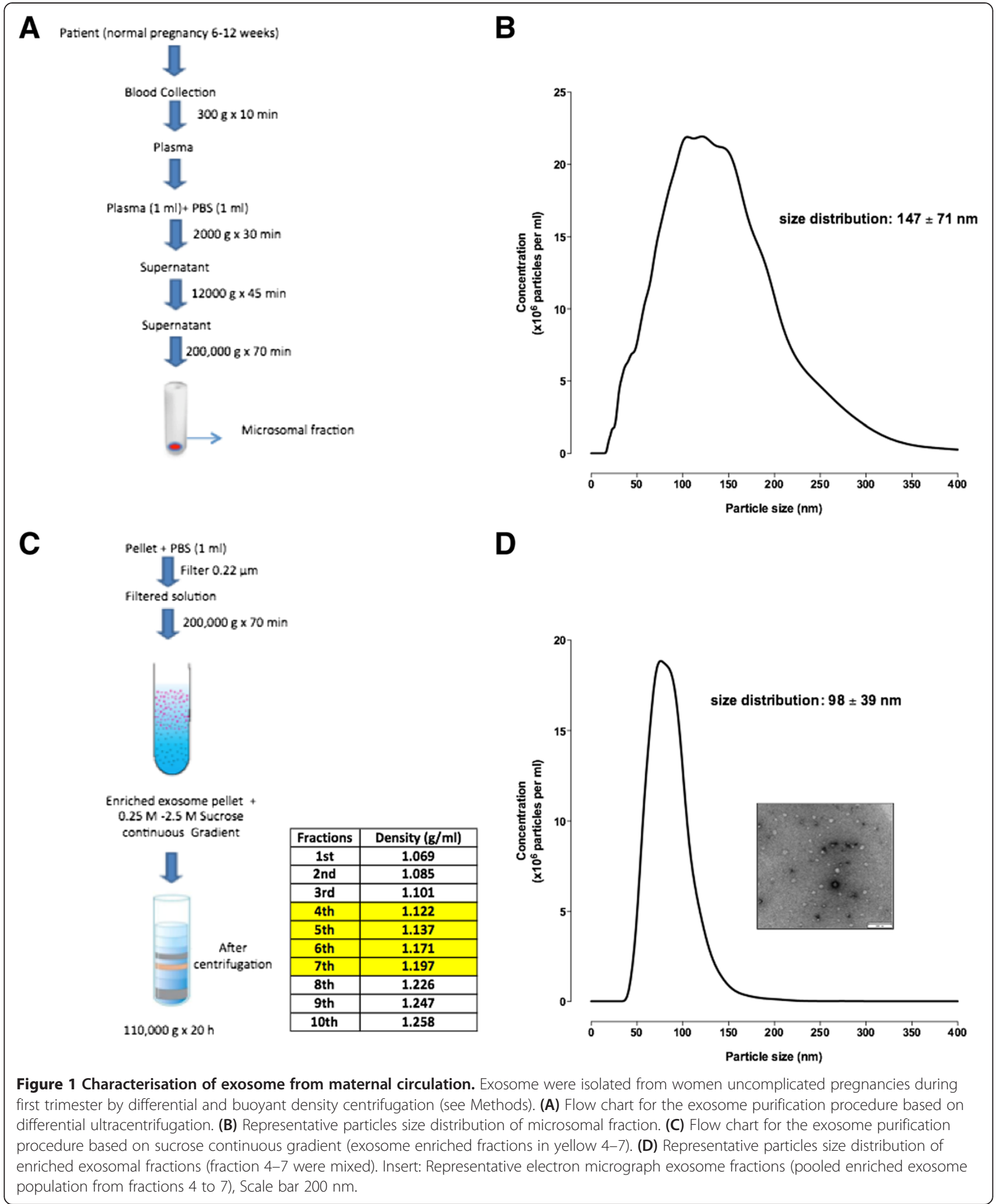

The number of exosomes present in the maternal plasma increased progressively during the first trimester, as well as the exosomal PLAP concentration.
We isolated exosomes from the maternal plasma by differential and buoyant density centrifugation using a sucrose continuous gradient $[7,17]$. The purification of 


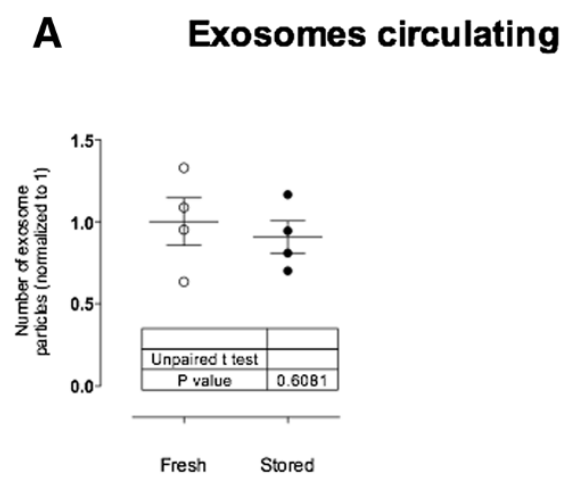

C

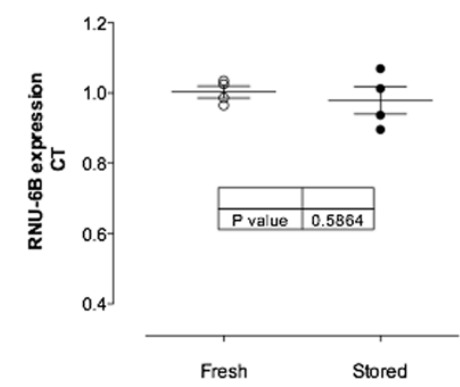

B

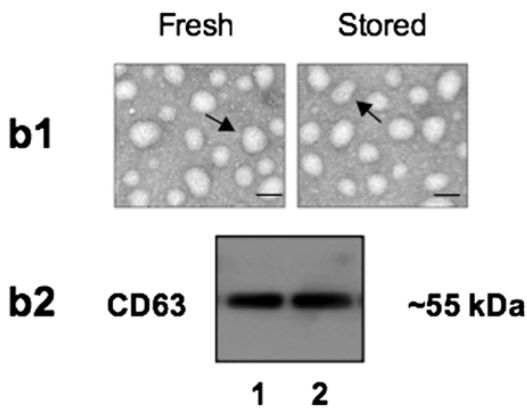

D MS/MS proteins

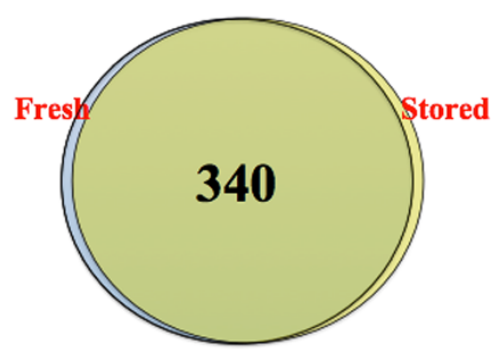

Figure 2 Characteristics of exosomes isolated from plasma immediately after phlebotomy ( () and after 30 days stored at $-80^{\circ} \mathrm{C}(\bullet)$. (A) Number of exosome particles. (B) Exosomes characterization. b1: electron microscope (scale bar $100 \mathrm{~nm}$ ) and b2: Western blot for CD63 (exosomal marker); lane 1: Fresh and lane 2: stored. (C) Expression of miRNA RNU6B in exosomes. (D) Venn diagram of proteins identified in fresh and stored exosomes.

exosomes from plasma and other biological fluids is not trivial, however, the use of an automatic system for fraction collection after the sucrose continuous gradient enable a high-reproducibility density, and decreasing the coefficient of variation between samples. In addition, using purification method based on the density of exosomes discards vesicles with the same size of exosomes with no endosomal origin, increasing the purity of exosome samples.

Previous studies have established that extracellular vesicles, including exosomes are released under physiological and pathophysiological conditions as well as during gestation [18]. The release of these vesicles is increased during pregnancy in response to different pathological conditions, presumably due to exosomal secretion from the placental trophoblast cells to the maternal peripheral circulation $[19,20]$. In this study, we have established that exosomes are very stable when stored at $-80^{\circ} \mathrm{C}$. We obtained similar exosome yield from fresh and stored samples (i.e. plasma) and were able to identify gestational age differences in plasma exosome number in samples stored in long term. The isolation of exosomes from stored biofluids is the normal rather than the exception. These results are consistent with those of other studies [21,22] suggesting that the exosomal content is protected inside these vesicles, highlighting the potential use of exosomes as biomarker for their high stability under different conditions.

As exosomes carry different kinds of protein, mRNA and miRNA [23], engaging in cell-to-cell communication, it is likely that they play an important role in modifying the maternal physiological state to maintain a successful pregnancy [24]. Interestingly, in this study we found that placental-derived exosomes increased systematically during the first trimester as early as sixth week of pregnancy when the intervillous circulation is not fully established. However, it has been observed that communication between placental and fetal circulation occurs at the beginning of the fourth week post conception [25]. Moreover, the lacunar spaces are formed in the trophoblast from as early as nine days post-ovulation and maternal blood flows into the trophoblast lacunae between ten and eleven days after fecundation. In addition, it has been reported that the intervillous blood flow is present in an early stage (i.e. < seventh week) [26] and increases gradually from fourth week during the first trimester of pregnancy [27].

Trophoblast plugs occlude the spiral arteries to prevent the contact of maternal blood flow into the intervillous space, however, at the same time trophoblast plug are in contact with the maternal blood, and could releases soluble proteins (e.g. human chorionic gonadotropin, hCG) and 
Table 1 Common proteins identified in exosomes isolated from fresh plasma and after freeze/thawing cycles

\begin{tabular}{|c|c|c|c|c|}
\hline Protein ID & Symbol & Entrez gene name & Location & Type(s) \\
\hline A2MG_HUMAN & $\mathrm{A} 2 \mathrm{M}$ & alpha-2-macroglobulin & Extracellular Space & transporter \\
\hline A2ML1_HUMAN & A2ML1 & alpha-2-macroglobulin-like 1 & Cytoplasm & other \\
\hline ACACA_HUMAN & ACACA & acetyl-CoA carboxylase alpha & Cytoplasm & enzyme \\
\hline ACTN3_HUMAN & ACTN3 & actinin, alpha 3 & Plasma Membrane & other \\
\hline ADAL_HUMAN & ADAL & adenosine deaminase-like & Cytoplasm & enzyme \\
\hline ATS16_HUMAN & ADAMTS16 & $\begin{array}{l}\text { ADAM metallopeptidase with thrombospondin } \\
\text { type } 1 \text { motif, } 16\end{array}$ & Extracellular Space & other \\
\hline ATS9_HUMAN & ADAMTS9 & $\begin{array}{l}\text { ADAM metallopeptidase with thrombospondin } \\
\text { type } 1 \text { motif, } 9\end{array}$ & Extracellular Space & peptidase \\
\hline DSRAD_HUMAN & ADAR & adenosine deaminase, RNA-specific & Nucleus & enzyme \\
\hline ADCY7_HUMAN & ADCY7 & adenylate cyclase 7 & Plasma Membrane & enzyme \\
\hline KFA_HUMAN & AFMID & arylformamidase & Nucleus & enzyme \\
\hline ANGT_HUMAN & AGT & $\begin{array}{l}\text { angiotensinogen (serpin peptidase inhibitor, } \\
\text { clade } A \text {, member } 8 \text { ) }\end{array}$ & Extracellular Space & growth factor \\
\hline ALBU_HUMAN & ALB & albumin & Extracellular Space & transporter \\
\hline AMZ1_HUMAN & AMZ1 & archaelysin family metallopeptidase 1 & Other & peptidase \\
\hline ANK2_HUMAN & ANK2 & ankyrin 2, neuronal & Plasma Membrane & other \\
\hline ANKAR_HUMAN & ANKAR & ankyrin and armadillo repeat containing & Nucleus & transcription regulator \\
\hline AKD1B_HUMAN & ANKDD1B & ankyrin repeat and death domain containing $1 \mathrm{~B}$ & Other & other \\
\hline ANKL1_HUMAN & ANKLE1 & ankyrin repeat and LEM domain containing 1 & Other & other \\
\hline ANR12_HUMAN & ANKRD12 & ankyrin repeat domain 12 & Nucleus & other \\
\hline ANR26_HUMAN & ANKRD26 & ankyrin repeat domain 26 & Nucleus & transcription regulator \\
\hline ANKUB_HUMAN & ANKUB1 & ankyrin repeat and ubiquitin domain containing 1 & Other & other \\
\hline APOA1_HUMAN & APOA1 & apolipoprotein A-I & Extracellular Space & transporter \\
\hline APOB_HUMAN & APOB & apolipoprotein B & Extracellular Space & transporter \\
\hline APOL1_HUMAN & APOL1 & apolipoprotein L, 1 & Extracellular Space & transporter \\
\hline APOP1_HUMAN & APOPT1 & apoptogenic 1, mitochondrial & Cytoplasm & other \\
\hline DP13B_HUMAN & APPL2 & $\begin{array}{l}\text { adaptor protein, phosphotyrosine interaction, } \\
\text { PH domain and leucine zipper containing } 2\end{array}$ & Cytoplasm & other \\
\hline RHG15_HUMAN & ARHGAP15 & Rho GTPase activating protein 15 & Cytoplasm & other \\
\hline RHG08_HUMAN & $\begin{array}{l}\text { ARHGAP8/ } \\
\text { PRR5-ARHGAP8 }\end{array}$ & Rho GTPase activating protein 8 & Cytoplasm & other \\
\hline ARHGB_HUMAN & ARHGEF11 & Rho guanine nucleotide exchange factor (GEF) 11 & Cytoplasm & other \\
\hline ASPM_HUMAN & ASPM & $\begin{array}{l}\text { asp (abnormal spindle) homolog, microcephaly } \\
\text { associated (Drosophila) }\end{array}$ & Nucleus & other \\
\hline ATG2B_HUMAN & ATG2B & autophagy related $2 \mathrm{~B}$ & Other & other \\
\hline AT2A3_HUMAN & ATP2A3 & ATPase, $\mathrm{Ca}++$ transporting, ubiquitous & Cytoplasm & transporter \\
\hline RENR_HUMAN & ATP6AP2 & ATPase, $\mathrm{H}+$ transporting, lysosomal accessory protein 2 & Cytoplasm & transporter \\
\hline ATR_HUMAN & ATR & ataxia telangiectasia and Rad3 related & Nucleus & kinase \\
\hline B4GT7_HUMAN & B4GALT7 & xylosylprotein beta 1,4-galactosyltransferase, polypeptide 7 & Cytoplasm & enzyme \\
\hline BEND4_HUMAN & BEND4 & BEN domain containing 4 & Other & other \\
\hline OSTCN_HUMAN & BGLAP & bone gamma-carboxyglutamate (gla) protein & Extracellular Space & other \\
\hline BLM_HUMAN & BLM & Bloom syndrome, RecQ helicase-like & Nucleus & enzyme \\
\hline BRCA2_HUMAN & BRCA2 & breast cancer 2, early onset & Nucleus & transcription regulator \\
\hline BRPF1_HUMAN & BRPF1 & bromodomain and PHD finger containing, 1 & Nucleus & transporter \\
\hline CSO68_HUMAN & C19orf68 & chromosome 19 open reading frame 68 & Other & other \\
\hline
\end{tabular}


Table 1 Common proteins identified in exosomes isolated from fresh plasma and after freeze/thawing cycles (Continued)

\begin{tabular}{|c|c|c|c|c|}
\hline CA174_HUMAN & C1orf174 & chromosome 1 open reading frame 174 & Nucleus & other \\
\hline CA228_HUMAN & C1orf228 & chromosome 1 open reading frame 228 & Other & other \\
\hline C1QC_HUMAN & $\mathrm{C} 1 \mathrm{QC}$ & complement component 1, q subcomponent, $\mathrm{C}$ chain & Extracellular Space & other \\
\hline CO3_HUMAN & C3 & complement component 3 & Extracellular Space & peptidase \\
\hline CO4A_HUMAN & $\mathrm{C} 4 \mathrm{~A} / \mathrm{C} 4 \mathrm{~B}$ & complement component 4B (Chido blood group) & Extracellular Space & other \\
\hline C4BPA_HUMAN & C4BPA & complement component 4 binding protein, alpha & Extracellular Space & other \\
\hline CI078_HUMAN & C9orf78 & chromosome 9 open reading frame 78 & Other & other \\
\hline CAH3_HUMAN & CA3 & carbonic anhydrase III, muscle specific & Cytoplasm & enzyme \\
\hline CABIN_HUMAN & CABIN1 & calcineurin binding protein 1 & Nucleus & other \\
\hline CAND1_HUMAN & CAND1 & cullin-associated and neddylation-dissociated 1 & Cytoplasm & transcription regulator \\
\hline CAN1_HUMAN & CAPN1 & calpain 1, (mu/l) large subunit & Cytoplasm & peptidase \\
\hline CAN2_HUMAN & CAPN2 & calpain 2, (m/II) large subunit & Cytoplasm & peptidase \\
\hline CASC5_HUMAN & CASC5 & cancer susceptibility candidate 5 & Nucleus & other \\
\hline C8AP2_HUMAN & CASP8AP2 & caspase 8 associated protein 2 & Nucleus & transcription regulator \\
\hline CC154_HUMAN & CCDC154 & coiled-coil domain containing 154 & Other & other \\
\hline CC171_HUMAN & CCDC171 & coiled-coil domain containing 171 & Other & other \\
\hline CCD30_HUMAN & CCDC30 & coiled-coil domain containing 30 & Other & other \\
\hline CCD37_HUMAN & CCDC37 & coiled-coil domain containing 37 & Other & other \\
\hline CCD80_HUMAN & CCDC80 & coiled-coil domain containing 80 & Nucleus & other \\
\hline CCHCR_HUMAN & CCHCR1 & coiled-coil alpha-helical rod protein 1 & Cytoplasm & other \\
\hline CENPH_HUMAN & CENPH & centromere protein $\mathrm{H}$ & Nucleus & other \\
\hline CP135_HUMAN & CEP135 & centrosomal protein $135 \mathrm{kDa}$ & Cytoplasm & other \\
\hline CFAH_HUMAN & $\mathrm{CFH}$ & complement factor $\mathrm{H}$ & Extracellular Space & other \\
\hline CHD4_HUMAN & CHD4 & chromodomain helicase DNA binding protein 4 & Nucleus & enzyme \\
\hline CHD9_HUMAN & CHD9 & chromodomain helicase DNA binding protein 9 & Cytoplasm & other \\
\hline ACHG_HUMAN & CHRNG & cholinergic receptor, nicotinic, gamma (muscle) & Plasma Membrane & transmembrane receptor \\
\hline CHSTB_HUMAN & CHST11 & carbohydrate (chondroitin 4) sulfotransferase 11 & Cytoplasm & enzyme \\
\hline CHSS3_HUMAN & $\mathrm{CHSY} 3$ & chondroitin sulfate synthase 3 & Cytoplasm & enzyme \\
\hline CILP1_HUMAN & CILP & $\begin{array}{l}\text { cartilage intermediate layer protein, nucleotide } \\
\text { pyrophosphohydrolase }\end{array}$ & Extracellular Space & phosphatase \\
\hline CLNK_HUMAN & CLNK & cytokine-dependent hematopoietic cell linker & Cytoplasm & other \\
\hline CLUS_HUMAN & CLU & clusterin & Cytoplasm & other \\
\hline CMBL_HUMAN & CMBL & carboxymethylenebutenolidase homolog (Pseudomonas) & Cytoplasm & enzyme \\
\hline CNO6L_HUMAN & CNOT6L & CCR4-NOT transcription complex, subunit 6-like & Cytoplasm & enzyme \\
\hline COPA1_HUMAN & COL25A1 & collagen, type XXV, alpha 1 & Cytoplasm & other \\
\hline CROCC_HUMAN & CROCC & ciliary rootlet coiled-coil, rootletin & Plasma Membrane & other \\
\hline CSRN1_HUMAN & CSRNP1 & cysteine-serine-rich nuclear protein 1 & Nucleus & transcription regulator \\
\hline DIAC_HUMAN & CTBS & chitobiase, di-N-acetyl- & Cytoplasm & enzyme \\
\hline CUL9_HUMAN & CUL9 & cullin 9 & Cytoplasm & other \\
\hline CWC25_HUMAN & CWC25 & $\begin{array}{l}\text { CWC25 spliceosome-associated protein homolog } \\
\text { (S. cerevisiae) }\end{array}$ & Other & other \\
\hline CP1A2_HUMAN & CYP1A2 & cytochrome P450, family 1 , subfamily A, polypeptide 2 & Cytoplasm & enzyme \\
\hline CP51A_HUMAN & CYP51A1 & cytochrome P450, family 51, subfamily A, polypeptide 1 & Cytoplasm & enzyme \\
\hline DAPL1_HUMAN & DAPL1 & death associated protein-like 1 & Other & other \\
\hline DCAF6_HUMAN & DCAF6 & DDB1 and CUL4 associated factor 6 & Nucleus & transcription regulator \\
\hline
\end{tabular}


Table 1 Common proteins identified in exosomes isolated from fresh plasma and after freeze/thawing cycles (Continued)

\begin{tabular}{|c|c|c|c|c|}
\hline DCR1B_HUMAN & DCLRE1B & DNA cross-link repair 1B & Nucleus & enzyme \\
\hline DCSTP_HUMAN & DCSTAMP & dendrocyte expressed seven transmembrane protein & Plasma Membrane & other \\
\hline DCX_HUMAN & DCX & doublecortin & Cytoplasm & other \\
\hline DDX51_HUMAN & DDX51 & DEAD (Asp-Glu-Ala-Asp) box polypeptide 51 & Other & enzyme \\
\hline DEN2D_HUMAN & DENND2D & DENN/MADD domain containing 2D & Cytoplasm & other \\
\hline DESM_HUMAN & DES & desmin & Cytoplasm & other \\
\hline DGAT1_HUMAN & DGAT1 & diacylglycerol O-acyltransferase 1 & Cytoplasm & enzyme \\
\hline DGC14_HUMAN & DGCR14 & DiGeorge syndrome critical region gene 14 & Nucleus & other \\
\hline DHX30_HUMAN & $\mathrm{DHX30}$ & DEAH (Asp-Glu-Ala-His) box helicase 30 & Nucleus & enzyme \\
\hline DIP2B_HUMAN & DIP2B & DIP2 disco-interacting protein 2 homolog B (Drosophila) & Cytoplasm & other \\
\hline DMXL1_HUMAN & DMXL1 & Dmx-like 1 & Extracellular Space & other \\
\hline DYH17_HUMAN & DNAH17 & dynein, axonemal, heavy chain 17 & Cytoplasm & other \\
\hline DYH2_HUMAN & DNAH2 & dynein, axonemal, heavy chain 2 & Other & other \\
\hline DYH3_HUMAN & DNAH3 & dynein, axonemal, heavy chain 3 & Extracellular Space & enzyme \\
\hline DYH5_HUMAN & DNAH5 & dynein, axonemal, heavy chain 5 & Cytoplasm & enzyme \\
\hline DNJC7_HUMAN & DNAJC7 & DnaJ (Hsp40) homolog, subfamily C, member 7 & Cytoplasm & other \\
\hline DOP1_HUMAN & DOPEY1 & dopey family member 1 & Cytoplasm & other \\
\hline DSCAM_HUMAN & DSCAM & Down syndrome cell adhesion molecule & Plasma Membrane & other \\
\hline DUS3L_HUMAN & DUS3L & dihydrouridine synthase 3-like (S. cerevisiae) & Other & other \\
\hline DYHC2_HUMAN & DYNC2H1 & dynein, cytoplasmic 2, heavy chain 1 & Cytoplasm & other \\
\hline COE2_HUMAN & EBF2 & early B-cell factor 2 & Nucleus & other \\
\hline EBP_HUMAN & EBP & emopamil binding protein (sterol isomerase) & Cytoplasm & enzyme \\
\hline EIF3C_HUMAN & EIF3C & eukaryotic translation initiation factor 3 , subunit $C$ & Other & translation regulator \\
\hline ENPP1_HUMAN & ENPP1 & ectonucleotide pyrophosphatase/phosphodiesterase 1 & Plasma Membrane & enzyme \\
\hline ENPP5_HUMAN & ENPP5 & $\begin{array}{l}\text { ectonucleotide pyrophosphatase/phosphodiesterase } \\
5 \text { (putative) }\end{array}$ & Extracellular Space & enzyme \\
\hline PERE_HUMAN & EPX & eosinophil peroxidase & Cytoplasm & enzyme \\
\hline EXOS1_HUMAN & EXOSC1 & exosome component 1 & Nucleus & enzyme \\
\hline F150A_HUMAN & FAM150A & family with sequence similarity 150 , member A & Other & other \\
\hline F196B_HUMAN & FAM196B & family with sequence similarity 196 , member B & Other & other \\
\hline F208B_HUMAN & FAM208B & family with sequence similarity 208 , member B & Other & other \\
\hline YV021_HUMAN & FAM230B & $\begin{array}{l}\text { family with sequence similarity } 230, \text { member B } \\
\text { (non-protein coding) }\end{array}$ & Extracellular Space & other \\
\hline FA78B_HUMAN & FAM78B & family with sequence similarity 78, member $B$ & Other & other \\
\hline FBF1_HUMAN & FBF1 & Fas (TNFRSF6) binding factor 1 & Nucleus & other \\
\hline FIBA_HUMAN & FGA & fibrinogen alpha chain & Extracellular Space & other \\
\hline FIBB_HUMAN & FGB & fibrinogen beta chain & Extracellular Space & other \\
\hline FR1OP_HUMAN & FGFR1OP & FGFR1 oncogene partner & Cytoplasm & kinase \\
\hline FGRL1_HUMAN & FGFRL1 & fibroblast growth factor receptor-like 1 & Plasma Membrane & transmembrane receptor \\
\hline FIBG_HUMAN & FGG & fibrinogen gamma chain & Extracellular Space & other \\
\hline FHAD1_HUMAN & FHAD1 & forkhead-associated (FHA) phosphopeptide binding domain 1 & Other & other \\
\hline FIGL2_HUMAN & FIGNL2 & fidgetin-like 2 & Other & other \\
\hline FLNB_HUMAN & FLNB & filamin B, beta & Cytoplasm & other \\
\hline FINC_HUMAN & FN1 & fibronectin 1 & Extracellular Space & enzyme \\
\hline FRMD3_HUMAN & FRMD3 & FERM domain containing 3 & Other & other \\
\hline
\end{tabular}


Table 1 Common proteins identified in exosomes isolated from fresh plasma and after freeze/thawing cycles (Continued)

\begin{tabular}{|c|c|c|c|c|}
\hline G6PC2_HUMAN & G6PC2 & glucose-6-phosphatase, catalytic, 2 & Cytoplasm & phosphatase \\
\hline GAK_HUMAN & GAK & cyclin G associated kinase & Nucleus & kinase \\
\hline GSHO_HUMAN & GCLM & glutamate-cysteine ligase, modifier subunit & Cytoplasm & enzyme \\
\hline GCN1L_HUMAN & GCN1L1 & $\begin{array}{l}\text { GCN1 general control of amino-acid synthesis 1-like } \\
1 \text { (yeast) }\end{array}$ & Cytoplasm & translation regulator \\
\hline CXB1_HUMAN & GJB1 & gap junction protein, beta 1, $32 \mathrm{kDa}$ & Plasma Membrane & transporter \\
\hline GLRA2_HUMAN & GLRA2 & glycine receptor, alpha 2 & Plasma Membrane & ion channel \\
\hline GMEB1_HUMAN & GMEB1 & glucocorticoid modulatory element binding protein 1 & Nucleus & transcription regulator \\
\hline GOGA3_HUMAN & GOLGA3 & golgin $A 3$ & Cytoplasm & transporter \\
\hline AATC_HUMAN & GOT1 & glutamic-oxaloacetic transaminase 1 , soluble & Cytoplasm & enzyme \\
\hline GRID2_HUMAN & GRID2 & glutamate receptor, ionotropic, delta 2 & Plasma Membrane & ion channel \\
\hline GSAP_HUMAN & GSAP & gamma-secretase activating protein & Cytoplasm & peptidase \\
\hline GSAS1_HUMAN & GSN-AS1 & GSN antisense RNA 1 & Other & other \\
\hline GSHB_HUMAN & GSS & glutathione synthetase & Cytoplasm & enzyme \\
\hline HERC1_HUMAN & HERC1 & $\begin{array}{l}\text { HECT and RLD domain containing E3 ubiquitin } \\
\text { protein ligase family member } 1\end{array}$ & Cytoplasm & other \\
\hline HES1_HUMAN & HES1 & hes family bHLH transcription factor 1 & Nucleus & transcription regulator \\
\hline HILS1_HUMAN & HILS1 & histone linker $\mathrm{H} 1$ domain, spermatid-specific 1, pseudogene & Nucleus & other \\
\hline HIP1_HUMAN & HIP1 & huntingtin interacting protein 1 & Cytoplasm & other \\
\hline HJURP_HUMAN & HJURP & Holliday junction recognition protein & Nucleus & other \\
\hline HPTR_HUMAN & HPR & haptoglobin-related protein & Extracellular Space & peptidase \\
\hline 5HT2A_HUMAN & HTR2A & $\begin{array}{l}\text { 5-hydroxytryptamine (serotonin) receptor } 2 \mathrm{~A} \text {, } \\
\mathrm{G} \text { protein-coupled }\end{array}$ & Plasma Membrane & $\begin{array}{l}\text { G-protein coupled } \\
\text { receptor }\end{array}$ \\
\hline 12302_HUMAN & IDO2 & indoleamine 2,3-dioxygenase 2 & Cytoplasm & enzyme \\
\hline GILT_HUMAN & $\mathrm{IFI} 30$ & interferon, gamma-inducible protein 30 & Cytoplasm & enzyme \\
\hline IGHA1_HUMAN & $|\mathrm{GHA}|$ & immunoglobulin heavy constant alpha 1 & Extracellular Space & other \\
\hline IGHG1_HUMAN & $\mid G H G 1$ & immunoglobulin heavy constant gamma 1 (G1m marker) & Extracellular Space & other \\
\hline IGHM_HUMAN & IGHM & immunoglobulin heavy constant mu & Plasma Membrane & transmembrane receptor \\
\hline IGJ_HUMAN & IG」 & $\begin{array}{l}\text { immunoglobulin J polypeptide, linker protein } \\
\text { for immunoglobulin alpha and mu polypeptides }\end{array}$ & Extracellular Space & other \\
\hline IGKC_HUMAN & IGKC & immunoglobulin kappa constant & Extracellular Space & other \\
\hline KV401_HUMAN & IGKV4-1 & immunoglobulin kappa variable 4-1 & Extracellular Space & other \\
\hline LAC1_HUMAN & IGLC1 & immunoglobulin lambda constant 1 (Mcg marker) & Cytoplasm & other \\
\hline LAC2_HUMAN & IGLC2 & immunoglobulin lambda constant 2 (Kern-Oz- marker) & Extracellular Space & other \\
\hline IHH_HUMAN & $\| \mathrm{H}$ & indian hedgehog & Extracellular Space & enzyme \\
\hline RED_HUMAN & $\mathbb{I K}$ & IK cytokine, down-regulator of HLA \| & Extracellular Space & cytokine \\
\hline IL1AP_HUMAN & IL1RAP & interleukin 1 receptor accessory protein & Plasma Membrane & transmembrane receptor \\
\hline IRPL2_HUMAN & IL1RAPL2 & interleukin 1 receptor accessory protein-like 2 & Plasma Membrane & transmembrane receptor \\
\hline IL26_HUMAN & IL26 & interleukin 26 & Extracellular Space & cytokine \\
\hline INCE_HUMAN & INCENP & inner centromere protein antigens 135/155 kDa & Nucleus & other \\
\hline IQCF6_HUMAN & IQCF6 & IQ motif containing F6 & Other & other \\
\hline JARD2_HUMAN & JARID2 & jumonji, AT rich interactive domain 2 & Nucleus & transcription regulator \\
\hline KTNB1_HUMAN & KATNB1 & katanin p80 (WD repeat containing) subunit B 1 & Cytoplasm & enzyme \\
\hline KCND2_HUMAN & KCND2 & potassium voltage-gated channel, Shal-related & Plasma Membrane & ion channel \\
\hline
\end{tabular}


Table 1 Common proteins identified in exosomes isolated from fresh plasma and after freeze/thawing cycles (Continued)

\begin{tabular}{|c|c|c|c|c|}
\hline KCNQ5_HUMAN & KCNQ5 & $\begin{array}{l}\text { potassium voltage-gated channel, KQT-like } \\
\text { subfamily, member } 5\end{array}$ & Plasma Membrane & ion channel \\
\hline KDM2B_HUMAN & $\mathrm{KDM} 2 \mathrm{~B}$ & lysine (K)-specific demethylase 2B & Nucleus & other \\
\hline KDM5A_HUMAN & KDM5A & lysine $(\mathrm{K})$-specific demethylase $5 \mathrm{~A}$ & Nucleus & transcription regulator \\
\hline TALD3_HUMAN & KIAA0586 & KIAA0586 & Cytoplasm & other \\
\hline K1161_HUMAN & KIAA1161 & KIAA1161 & Nucleus & other \\
\hline KI13A_HUMAN & KIF13A & kinesin family member $13 \mathrm{~A}$ & Cytoplasm & transporter \\
\hline KIF19_HUMAN & KIF19 & kinesin family member 19 & Extracellular Space & enzyme \\
\hline KIRR1_HUMAN & KIRREL & kin of IRRE like (Drosophila) & Plasma Membrane & other \\
\hline KLC2_HUMAN & $\mathrm{KLC2}$ & kinesin light chain 2 & Cytoplasm & other \\
\hline KLRF1_HUMAN & KLRF1 & killer cell lectin-like receptor subfamily F, member 1 & Plasma Membrane & transmembrane receptor \\
\hline LDB1_HUMAN & LDB1 & LIM domain binding 1 & Nucleus & transcription regulator \\
\hline LHPL3_HUMAN & LHFPL3 & lipoma HMGIC fusion partner-like 3 & Other & other \\
\hline LIPC_HUMAN & LIPC & lipase, hepatic & Extracellular Space & enzyme \\
\hline YP023_HUMAN & LOC100128265 & uncharacterized LOC100128265 & Other & other \\
\hline LRP1B_HUMAN & LRP1B & low density lipoprotein receptor-related protein 1B & Plasma Membrane & transmembrane receptor \\
\hline LTBP2_HUMAN & LTBP2 & latent transforming growth factor beta binding protein 2 & Extracellular Space & other \\
\hline LY75_HUMAN & LY75 & lymphocyte antigen 75 & Plasma Membrane & transmembrane receptor \\
\hline MACD1_HUMAN & MACROD1 & MACRO domain containing 1 & Cytoplasm & enzyme \\
\hline MANF_HUMAN & MANF & mesencephalic astrocyte-derived neurotrophic factor & Extracellular Space & other \\
\hline MLP3A_HUMAN & MAP1LC3A & microtubule-associated protein 1 light chain 3 alpha & Cytoplasm & other \\
\hline MAP4_HUMAN & MAP4 & microtubule-associated protein 4 & Cytoplasm & other \\
\hline MA7D3_HUMAN & MAP7D3 & MAP7 domain containing 3 & Cytoplasm & other \\
\hline MBD5_HUMAN & MBD5 & methyl-CpG binding domain protein 5 & Nucleus & other \\
\hline MDN1_HUMAN & MDN1 & MDN1, midasin homolog (yeast) & Nucleus & other \\
\hline MEX3B_HUMAN & MEX3B & mex-3 RNA binding family member B & Other & kinase \\
\hline MFNG_HUMAN & MFNG & MFNG O-fucosylpeptide 3-beta-N-acetylglucosaminyltransferase & Cytoplasm & enzyme \\
\hline MKL1_HUMAN & MKL1 & megakaryoblastic leukemia (translocation) 1 & Nucleus & transcription regulator \\
\hline MRE11_HUMAN & MRE11A & MRE11 meiotic recombination 11 homolog A (S. cerevisiae) & Nucleus & enzyme \\
\hline RM32_HUMAN & MRPL32 & mitochondrial ribosomal protein $\mathrm{L} 32$ & Cytoplasm & translation regulator \\
\hline MYBA_HUMAN & MYBL1 & v-myb avian myeloblastosis viral oncogene homolog-like 1 & Nucleus & transcription regulator \\
\hline MYO15_HUMAN & MYO15A & myosin XVA & Cytoplasm & other \\
\hline MYO3A_HUMAN & MYO3A & myosin IIIA & Cytoplasm & kinase \\
\hline MYO6_HUMAN & MYO6 & myosin VI & Cytoplasm & other \\
\hline ULA1_HUMAN & NAE1 & NEDD8 activating enzyme E1 subunit 1 & Cytoplasm & enzyme \\
\hline NUCL_HUMAN & $\mathrm{NCL}$ & nucleolin & Nucleus & other \\
\hline NCOA2_HUMAN & NCOA2 & nuclear receptor coactivator 2 & Nucleus & transcription regulator \\
\hline NEBU_HUMAN & NEB & nebulin & Cytoplasm & other \\
\hline NEDD4_HUMAN & NEDD4 & $\begin{array}{l}\text { neural precursor cell expressed, developmentally } \\
\text { down-regulated 4, E3 ubiquitin protein ligase }\end{array}$ & Cytoplasm & enzyme \\
\hline NHS_HUMAN & NHS & $\begin{array}{l}\text { Nance-Horan syndrome (congenital cataracts and } \\
\text { dental anomalies) }\end{array}$ & Nucleus & other \\
\hline NOA1_HUMAN & NOA1 & nitric oxide associated 1 & Cytoplasm & other \\
\hline NRX3A_HUMAN & NRXN3 & neurexin 3 & Other & transporter \\
\hline NSD1_HUMAN & NSD1 & nuclear receptor binding SET domain protein 1 & Nucleus & transcription regulator \\
\hline
\end{tabular}




\section{Table 1 Common proteins identified in exosomes isolated from fresh plasma and after freeze/thawing cycles} (Continued)

\begin{tabular}{|c|c|c|c|c|}
\hline NSN5C_HUMAN & NSUN5P2 & NOP2/Sun domain family, member 5 pseudogene 2 & Other & other \\
\hline NET5_HUMAN & NTN5 & netrin 5 & Other & other \\
\hline NUD15_HUMAN & NUDT15 & nudix (nucleoside diphosphate linked moiety X)-type motif 15 & Cytoplasm & phosphatase \\
\hline OBSCN_HUMAN & $\mathrm{OBSCN}$ & obscurin, cytoskeletal calmodulin and titin-interacting RhoGEF & Cytoplasm & kinase \\
\hline OCEL1_HUMAN & OCEL1 & occludin/ELL domain containing 1 & Other & other \\
\hline ODFP2_HUMAN & ODF2 & outer dense fiber of sperm tails 2 & Cytoplasm & other \\
\hline NOE2_HUMAN & OLFM2 & olfactomedin 2 & Cytoplasm & other \\
\hline OPN4_HUMAN & OPN4 & opsin 4 & Plasma Membrane & $\begin{array}{l}\text { G-protein coupled } \\
\text { receptor }\end{array}$ \\
\hline OR4K1_HUMAN & OR4K1 & olfactory receptor, family 4, subfamily K, member 1 & Plasma Membrane & $\begin{array}{l}\text { G-protein coupled } \\
\text { receptor }\end{array}$ \\
\hline PALB2_HUMAN & PALB2 & partner and localizer of BRCA2 & Nucleus & other \\
\hline PAR3L_HUMAN & PARD3B & par-3 family cell polarity regulator beta & Plasma Membrane & other \\
\hline PARP4_HUMAN & PARP4 & poly (ADP-ribose) polymerase family, member 4 & Cytoplasm & enzyme \\
\hline PCDH8_HUMAN & $\mathrm{PCDH} 8$ & protocadherin 8 & Plasma Membrane & other \\
\hline PCLO_HUMAN & PCLO & piccolo presynaptic cytomatrix protein & Cytoplasm & transporter \\
\hline PEAK1_HUMAN & PEAK1 & pseudopodium-enriched atypical kinase 1 & Plasma Membrane & kinase \\
\hline PEG10_HUMAN & PEG10 & paternally expressed 10 & Nucleus & other \\
\hline PER3_HUMAN & PER3 & period circadian clock 3 & Nucleus & other \\
\hline PFD6_HUMAN & PFDN6 & prefoldin subunit 6 & Cytoplasm & other \\
\hline PIGS_HUMAN & PIGS & phosphatidylinositol glycan anchor biosynthesis, class $S$ & Cytoplasm & enzyme \\
\hline P3C2A_HUMAN & PIK3C2A & $\begin{array}{l}\text { phosphatidylinositol-4-phosphate 3-kinase, } \\
\text { catalytic subunit type } 2 \text { alpha }\end{array}$ & Cytoplasm & kinase \\
\hline SOX_HUMAN & PIPOX & pipecolic acid oxidase & Cytoplasm & enzyme \\
\hline PLCD3_HUMAN & PLCD3 & phospholipase C, delta 3 & Cytoplasm & enzyme \\
\hline PLXA4_HUMAN & PLXNA4 & plexin A4 & Plasma Membrane & transmembrane receptor \\
\hline PNKD_HUMAN & PNKD & paroxysmal nonkinesigenic dyskinesia & Nucleus & other \\
\hline PNKP_HUMAN & PNKP & polynucleotide kinase 3'-phosphatase & Nucleus & kinase \\
\hline DPOLQ_HUMAN & POLQ & polymerase (DNA directed), theta & Nucleus & enzyme \\
\hline PMGT1_HUMAN & POMGNT1 & $\begin{array}{l}\text { protein O-linked mannose } \mathrm{N} \text {-acetylglucosaminyltransferase } \\
1 \text { (beta } 1,2-\text { ) }\end{array}$ & Cytoplasm & enzyme \\
\hline PPIG_HUMAN & PPIG & peptidylprolyl isomerase G (cyclophilin G) & Nucleus & enzyme \\
\hline PP12C_HUMAN & PPP1R12C & protein phosphatase 1 , regulatory subunit $12 \mathrm{C}$ & Cytoplasm & phosphatase \\
\hline PPT2_HUMAN & PPT2 & palmitoyl-protein thioesterase 2 & Cytoplasm & enzyme \\
\hline PREB_HUMAN & PREB & prolactin regulatory element binding & Nucleus & transcription regulator \\
\hline PPCEL_HUMAN & PREPL & prolyl endopeptidase-like & Other & peptidase \\
\hline PRG4_HUMAN & PRG4 & proteoglycan 4 & Extracellular Space & other \\
\hline PRP31_HUMAN & PRPF31 & pre-mRNA processing factor 31 & Nucleus & other \\
\hline PRC2A_HUMAN & PRRC2A & proline-rich coiled-coil 2A & Cytoplasm & other \\
\hline PSB3_HUMAN & PSMB3 & proteasome (prosome, macropain) subunit, beta type, 3 & Cytoplasm & peptidase \\
\hline PRS7_HUMAN & PSMC2 & proteasome (prosome, macropain) $26 \mathrm{~S}$ subunit, ATPase, 2 & Nucleus & peptidase \\
\hline PTPRM_HUMAN & PTPRM & protein tyrosine phosphatase, receptor type, $\mathrm{M}$ & Plasma Membrane & phosphatase \\
\hline PTTG3_HUMAN & PTTG3P & pituitary tumor-transforming 3, pseudogene & Other & other \\
\hline PZP_HUMAN & PZP & pregnancy-zone protein & Extracellular Space & other \\
\hline RAB10_HUMAN & RAB10 & RAB10, member RAS oncogene family & Cytoplasm & enzyme \\
\hline
\end{tabular}


Table 1 Common proteins identified in exosomes isolated from fresh plasma and after freeze/thawing cycles (Continued)

\begin{tabular}{|c|c|c|c|c|}
\hline RB3GP_HUMAN & RAB3GAP1 & RAB3 GTPase activating protein subunit 1 (catalytic) & Cytoplasm & other \\
\hline RAB6A_HUMAN & RAB6A & RAB6A, member RAS oncogene family & Cytoplasm & enzyme \\
\hline RAB8B_HUMAN & RAB8B & RAB8B, member RAS oncogene family & Cytoplasm & enzyme \\
\hline RGPA2_HUMAN & RALGAPA2 & Ral GTPase activating protein, alpha subunit 2 (catalytic) & Cytoplasm & other \\
\hline RBM23_HUMAN & RBM23 & RNA binding motif protein 23 & Nucleus & other \\
\hline REG1A_HUMAN & REG1A & regenerating islet-derived 1 alpha & Extracellular Space & growth factor \\
\hline RELN_HUMAN & RELN & reelin & Extracellular Space & peptidase \\
\hline RFC4_HUMAN & RFC4 & replication factor C (activator 1) 4, $37 \mathrm{kDa}$ & Nucleus & other \\
\hline RFX8_HUMAN & RFX8 & RFX family member 8 , lacking RFX DNA binding domain & Other & other \\
\hline RMND1_HUMAN & RMND1 & required for meiotic nuclear division 1 homolog (S. cerevisiae) & Cytoplasm & other \\
\hline RNF17_HUMAN & RNF17 & ring finger protein 17 & Cytoplasm & other \\
\hline RN213_HUMAN & RNF213 & ring finger protein 213 & Cytoplasm & enzyme \\
\hline RN219_HUMAN & RNF219 & ring finger protein 219 & Other & other \\
\hline FTM_HUMAN & RPGRIP1L & RPGRIP1-like & Cytoplasm & other \\
\hline RL29_HUMAN & RPL29 & ribosomal protein L29 & Cytoplasm & other \\
\hline RL37_HUMAN & RPL37 & ribosomal protein $L 37$ & Cytoplasm & other \\
\hline KS6A4_HUMAN & RPS6KA4 & ribosomal protein S6 kinase, 90 kDa, polypeptide 4 & Cytoplasm & kinase \\
\hline RTKN_HUMAN & RTKN & rhotekin & Cytoplasm & other \\
\hline RYR2_HUMAN & RYR2 & ryanodine receptor 2 (cardiac) & Plasma Membrane & ion channel \\
\hline SAMD8_HUMAN & SAMD8 & sterile alpha motif domain containing 8 & Cytoplasm & other \\
\hline SASH1_HUMAN & SASH1 & SAM and SH3 domain containing 1 & Extracellular Space & other \\
\hline UTER_HUMAN & SCGB1A1 & secretoglobin, family $1 \mathrm{~A}$, member 1 (uteroglobin) & Extracellular Space & cytokine \\
\hline SCUB3_HUMAN & SCUBE3 & signal peptide, CUB domain, EGF-like 3 & Plasma Membrane & other \\
\hline SPB9_HUMAN & SERPINB9 & serpin peptidase inhibitor, clade B (ovalbumin), member 9 & Cytoplasm & other \\
\hline SET1A_HUMAN & SETD1A & SET domain containing $1 \mathrm{~A}$ & Nucleus & ion channel \\
\hline SHAN1_HUMAN & SHANK1 & $\mathrm{SH} 3$ and multiple ankyrin repeat domains 1 & Cytoplasm & other \\
\hline SHAN3_HUMAN & SHANK3 & $\mathrm{SH} 3$ and multiple ankyrin repeat domains 3 & Plasma Membrane & other \\
\hline CTL1_HUMAN & SLC44A1 & solute carrier family 44 (choline transporter), member 1 & Plasma Membrane & transporter \\
\hline SNTAN_HUMAN & SNTN & sentan, cilia apical structure protein & Other & other \\
\hline SOLH1_HUMAN & SOHLH1 & $\begin{array}{l}\text { spermatogenesis and oogenesis specific basic } \\
\text { helix-loop-helix } 1\end{array}$ & Cytoplasm & transcription regulator \\
\hline SPAG7_HUMAN & SPAG7 & sperm associated antigen 7 & Nucleus & other \\
\hline SPA2L_HUMAN & SPATA2L & spermatogenesis associated 2-like & Other & other \\
\hline CYTSB_HUMAN & SPECC1 & $\begin{array}{l}\text { sperm antigen with calponin homology and } \\
\text { coiled-coil domains } 1\end{array}$ & Nucleus & other \\
\hline SPO11_HUMAN & SPO11 & SPO11 meiotic protein covalently bound to DSB & Nucleus & enzyme \\
\hline SPTN5_HUMAN & SPTBN5 & spectrin, beta, non-erythrocytic 5 & Plasma Membrane & other \\
\hline SRGP2_HUMAN & SRGAP2 & SLIT-ROBO Rho GTPase activating protein 2 & Cytoplasm & other \\
\hline SRG2C_HUMAN & SRGAP2C & SLIT-ROBO Rho GTPase activating protein $2 \mathrm{C}$ & Other & other \\
\hline SIA7B_HUMAN & ST6GALNAC2 & $\begin{array}{l}\text { ST6 (alpha-N-acetyl-neuraminyl-2,3-beta-galactosyl-1,3)- } \\
\mathrm{N} \text {-acetylgalactosaminide alpha-2,6-sialyltransferase } 2\end{array}$ & Cytoplasm & enzyme \\
\hline STXB1_HUMAN & STXBP1 & syntaxin binding protein 1 & Cytoplasm & transporter \\
\hline SP2OH_HUMAN & SUPT2OH & suppressor of Ty 20 homolog (S. cerevisiae) & Nucleus & other \\
\hline SPT6H_HUMAN & SUPT6H & suppressor of Ty 6 homolog (S. cerevisiae) & Nucleus & transcription regulator \\
\hline
\end{tabular}




\section{Table 1 Common proteins identified in exosomes isolated from fresh plasma and after freeze/thawing cycles} (Continued)

\begin{tabular}{|c|c|c|c|c|}
\hline SVEP1_HUMAN & SVEP1 & $\begin{array}{l}\text { sushi, von Willebrand factor type A, EGF and pentraxin } \\
\text { domain containing } 1\end{array}$ & Cytoplasm & other \\
\hline SYNJ1_HUMAN & SYNJ1 & synaptojanin 1 & Cytoplasm & phosphatase \\
\hline TADA3_HUMAN & TADA3 & transcriptional adaptor 3 & Nucleus & transcription regulator \\
\hline TBX20_HUMAN & TBX20 & T-box 20 & Nucleus & transcription regulator \\
\hline TDRD1_HUMAN & TDRD1 & tudor domain containing 1 & Cytoplasm & other \\
\hline TET1_HUMAN & TET1 & tet methylcytosine dioxygenase 1 & Nucleus & other \\
\hline THMS1_HUMAN & THEMIS & thymocyte selection associated & Cytoplasm & other \\
\hline TLK2_HUMAN & TLK2 & tousled-like kinase 2 & Cytoplasm & kinase \\
\hline TM131_HUMAN & TMEM131 & transmembrane protein 131 & Extracellular Space & other \\
\hline T132C_HUMAN & TMEM132C & transmembrane protein $132 \mathrm{C}$ & Other & other \\
\hline T151A_HUMAN & TMEM151A & transmembrane protein $151 \mathrm{~A}$ & Other & other \\
\hline TM232_HUMAN & TMEM232 & transmembrane protein 232 & Other & other \\
\hline TNFA_HUMAN & TNF & tumor necrosis factor & Extracellular Space & cytokine \\
\hline TPD54_HUMAN & TPD52L2 & tumor protein D52-like 2 & Cytoplasm & other \\
\hline TRML4_HUMAN & TREML4 & triggering receptor expressed on myeloid cells-like 4 & Other & other \\
\hline TRI32_HUMAN & TRIM32 & tripartite motif containing 32 & Nucleus & transcription regulator \\
\hline TRI65_HUMAN & TRIM65 & tripartite motif containing 65 & Other & other \\
\hline TARA_HUMAN & TRIOBP & TRIO and F-actin binding protein & Nucleus & other \\
\hline TRIPB_HUMAN & TRIP11 & thyroid hormone receptor interactor 11 & Cytoplasm & transcription regulator \\
\hline TROAP_HUMAN & TROAP & trophinin associated protein & Cytoplasm & peptidase \\
\hline TRPC5_HUMAN & TRPC5 & $\begin{array}{l}\text { transient receptor potential cation channel, } \\
\text { subfamily C, member } 5\end{array}$ & Plasma Membrane & ion channel \\
\hline TSG13_HUMAN & TSGA13 & testis specific, 13 & Other & other \\
\hline TTC12_HUMAN & TTC12 & tetratricopeptide repeat domain 12 & Other & other \\
\hline TITIN_HUMAN & TTN & titin & Cytoplasm & kinase \\
\hline GCP6_HUMAN & TUBGCP6 & tubulin, gamma complex associated protein 6 & Cytoplasm & other \\
\hline TRXR3_HUMAN & TXNRD3 & thioredoxin reductase 3 & Cytoplasm & enzyme \\
\hline UBQLN_HUMAN & UBQLNL & ubiquilin-like & Other & other \\
\hline UCKL1_HUMAN & UCKL1 & uridine-cytidine kinase 1 -like 1 & Cytoplasm & kinase \\
\hline UGDH_HUMAN & UGDH & UDP-glucose 6-dehydrogenase & Nucleus & enzyme \\
\hline USP9X_HUMAN & USP9X & ubiquitin specific peptidase 9, X-linked & Plasma Membrane & peptidase \\
\hline UTRO_HUMAN & UTRN & utrophin & Plasma Membrane & transmembrane receptor \\
\hline VP13C_HUMAN & VPS13C & vacuolar protein sorting 13 homolog C (S. cerevisiae) & Cytoplasm & other \\
\hline WAC_HUMAN & WAC & WW domain containing adaptor with coiled-coil & Nucleus & other \\
\hline WDR1_HUMAN & WDR1 & WD repeat domain 1 & Extracellular Space & other \\
\hline WDR35_HUMAN & WDR35 & WD repeat domain 35 & Cytoplasm & other \\
\hline WDR43_HUMAN & WDR43 & WD repeat domain 43 & Nucleus & other \\
\hline WFDC3_HUMAN & WFDC3 & WAP four-disulfide core domain 3 & Extracellular Space & other \\
\hline YIPF1_HUMAN & YIPF1 & Yip1 domain family, member 1 & Cytoplasm & other \\
\hline NIPA_HUMAN & $\mathrm{ZC} 3 \mathrm{HCl}$ & zinc finger, C3HC-type containing 1 & Nucleus & other \\
\hline ZFHX4_HUMAN & $\mathrm{ZFHX} 4$ & zinc finger homeobox 4 & Extracellular Space & other \\
\hline ZF64B_HUMAN & ZFP64 & ZFP64 zinc finger protein & Nucleus & other \\
\hline ZN132_HUMAN & ZNF132 & zinc finger protein 132 & Nucleus & other \\
\hline ZNF14_HUMAN & ZNF14 & zinc finger protein 14 & Nucleus & transcription regulator \\
\hline
\end{tabular}


Table 1 Common proteins identified in exosomes isolated from fresh plasma and after freeze/thawing cycles (Continued)

\begin{tabular}{llll}
\hline ZN215_HUMAN & ZNF215 & zinc finger protein 215 & Nucleus \\
Z286B_HUMAN & ZNF286B & zinc finger protein 286B & Other \\
ZN345_HUMAN & ZNF345 & zinc finger protein 345 & Nucleus \\
ZN532_HUMAN & ZNF532 & zinc finger protein 532 & Other \\
ZN561_HUMAN & ZNF561 & zinc finger protein 561 & Other \\
ZN624_HUMAN & ZNF624 & zinc finger protein 624 & Nucleus \\
ZNF74_HUMAN & ZNF74 & zinc finger protein 74 & Nucleus \\
\hline
\end{tabular}

List of common exosomal proteins are presented as Protein ID, Symbol, Entrez Gene Name, Location and type. No significant differences were observed en exosomal protein content from fresh or frozen plasma (coefficient of variation $<5 \%$ ) after different freeze thawing cycle from the same sample.

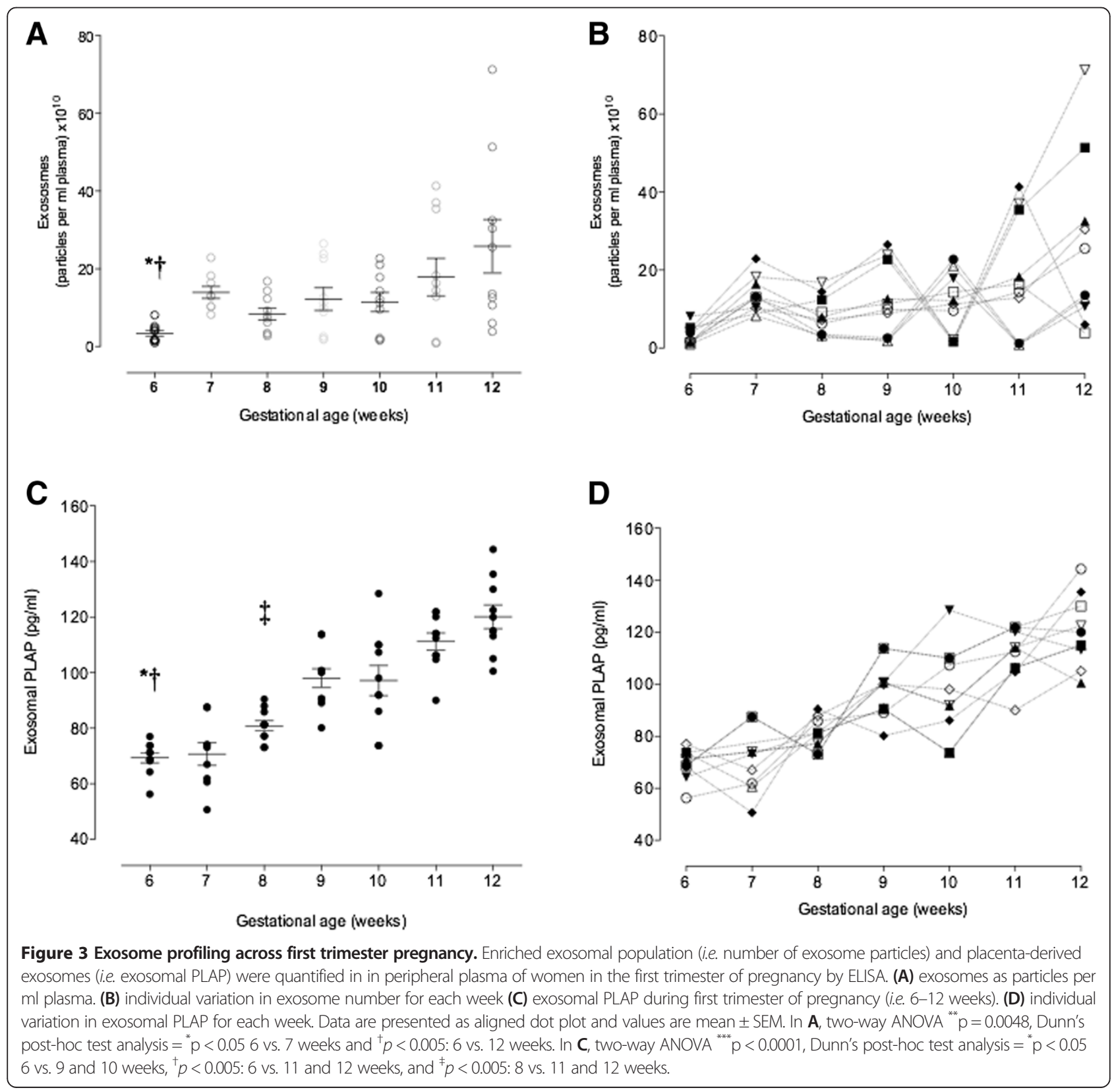




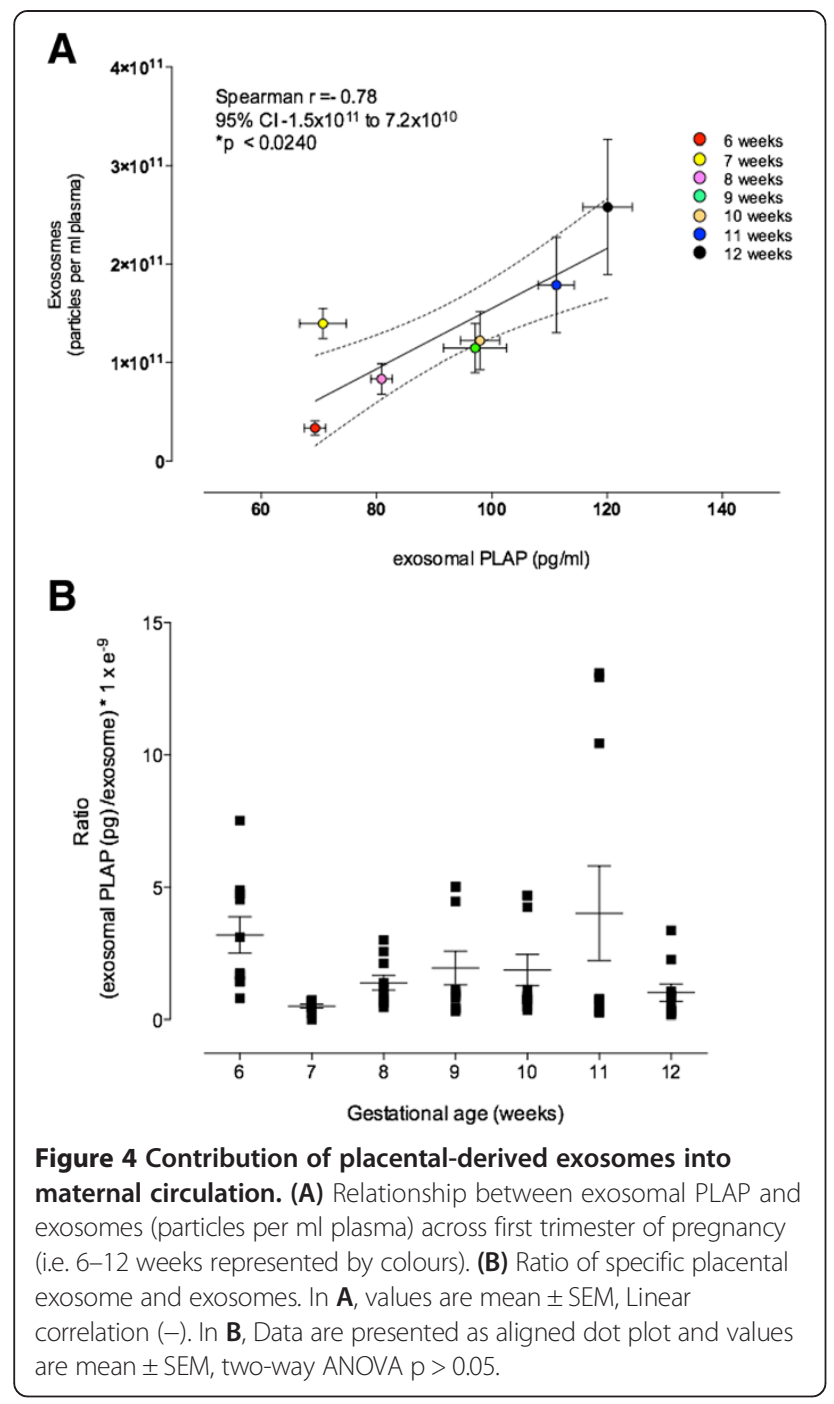

vesicles (e.g. nanovesicles) into maternal circulation. Interesting to highlight that hCG can be measured in maternal plasma as early as 4 weeks of gestation, confirming the presence of molecules released from the trophoblast in early pregnancy. Moreover, $\beta$-hCG and pregnancy-associated plasma protein A (PAPP-A) have been measured in maternal plasma as early as 6 weeks of gestation [28].

Specific placental-derived exosomes were quantified in the maternal circulation using the immunoreactive placental protein PLAP. Recent studies have demonstrated the presence of exosomes-PLAP ${ }^{\text {ive }}$ only in peripheral circulation of pregnant women $[7,29]$. PLAP is an integral membrane protein (enzyme) unique to the placenta (it has also been observed in some gynaecologic cancers), produced mainly by syncytiotrophoblast [30,31]. Nevertheless, PLAP expression has been found in primary trophoblast cytotrophoblast cells [7] and ED27 trophoblast-like cells, both isolated from first trimester chorionic villi, and also in JEG-3 cells (a extravillous trophoblast model) [32].
In addition, using immunohistochemistry stain for PLAP, the majority of chorionic trophoblastic cells were positive for PLAP [33]. During the first trimester of pregnancy, the release of placental exosomes into the maternal blood may result from extravillous trophoblast and/or syncytiotrophoblast cells; however, while a definitive answer awaits further investigation, it is of relevance to note that fetal cells are present in maternal blood from 4 weeks of pregnancy and that trophoblast cells invade the decidua and myometrium from the time of implantation. Thus, a cellular and exosomal pathway exists for delivery into the maternal circulation.

Recently, several attempts and techniques were undertaken to determine and characterize the exosomal content in different biological fluids including normal human blood plasma [34-36]. As, the content of these released exosomes are placenta- specific [37], studying these nanovesicles is excellent method to understand the different processes occurring during embryo/fetal development and the feto-maternal interaction. Exosome analysis provides diagnostic and therapeutic potential, and biomarker opportunities for the early detection of diseases [38-40]. To date, several research studies have been performed to identify the morphologic and proteomic characteristics of exosomes released from the placental extravilous trophoblast cells and expression profile of these exosomal contents relates to common pregnancy conditions $[8,41,42]$. However, all these studies considered the late second or third trimester of pregnancy plasma samples for analysis.

\section{Conclusions}

In conclusion, this study present longitudinal data on placental-derived exosomes in the first trimester of pregnancy, starting from as early as 6 weeks after implantation. Early detection of women at risk of complications of pregnancy would provide opportunity to evaluate appropriate intervention strategies to limit acute adverse squeal. The rationale for developing early pregnancy screening tests is not only for the management of the contemporaneous pregnancy but also to optimise lifelong and intergenerational health. If this can be achieved, it will provide an opportunity for early assignment of risk and the implementation of an alternative clinical management strategy to improve outcome for both the mother and baby.

\section{Competing interests}

The authors declare that they have no competing interests.

\section{Authors' contributions}

SS, KSR, and CS contributed in generating experimental data. CS, MDM and GER contributed in discussion and reviewed/edited manuscript. AP and SEI contributed obtaining clinical samples and management of patients. SS, CS and GER wrote the manuscript and drew the figures. All authors read and approved the final manuscript. 


\section{Acknowledgements}

We acknowledge the assistance of Dr. Jamie Riches and Dra. Rachel Hancock of the Central Analytical Research Facility, Institute for Future Environments, Queensland University of Technology (QUT) for the electron microscope analyses. This project was supported, in part by funding from Therapeutics Innovation Australia.

\section{Author details}

${ }^{1} \cup Q$ Centre for Clinical Research, Centre for Clinical Diagnostics, Royal Brisbane and Women's Hospital, University of Queensland, Building 71/918, Herston QLD 4029, Queensland, Australia. ${ }^{2}$ Department of Obstetrics and Gynaecology, Faculty of Medicine, Universidad de los Andes, Santiago, Chile. ${ }^{3}$ Department of Obstetrics and Gynaecology, Perinatal unit, Clinica Dávila, Santiago, Chile.

Received: 14 May 2014 Accepted: 10 July 2014

Published: 8 August 2014

\section{References}

1. Liou JD, Pao CC, Hor JJ, Kao SM: Fetal cells in the maternal circulation during first trimester in pregnancies. Hum Genet 1993, 92:309-311.

2. Wataganara T, Chen AY, LeShane ES, Sullivan LM, Borgatta L, Bianchi DW, Johnson KL: Cell-free fetal DNA levels in maternal plasma after elective first-trimester termination of pregnancy. Fertil Steril 2004, 81:638-644.

3. Salomon C, Kobayashi M, Ashman K, Sobrevia L, Mitchell MD, Rice GE: Hypoxia-induced changes in the bioactivity of cytotrophoblast-derived exosomes. PLoS One 2013, 8:e79636.

4. Salomon C, Ryan J, Sobrevia L, Kobayashi M, Ashman K, Mitchell M, Rice GE: Exosomal Signaling during Hypoxia Mediates Microvascular Endothelial Cell Migration and Vasculogenesis. PLoS One 2013, 8:e68451.

5. Tolosa JM, Schjenken JE, Clifton VL, Vargas A, Barbeau B, Lowry P, Maiti K, Smith R: The endogenous retroviral envelope protein syncytin-1 inhibits LPS/PHA-stimulated cytokine responses in human blood and is sorted into placental exosomes. Placenta 2012, 33:933-941.

6. Delorme-Axford E, Donker RB, Mouillet JF, Chu T, Bayer A, Ouyang Y, Wang T, Stolz DB, Sarkar SN, Morelli AE, Sadovsky Y, Coyne CB: Human placental trophoblasts confer viral resistance to recipient cells. Proc Natl Acad Sci U S A 2013, 110:12048-12053.

7. Salomon C, Torres MJ, Kobayashi M, Scholz-Romero K, Sobrevia L, Dobierzewska A, Illanes SE, Mitchell MD, Rice GE: A gestational profile of placental exosomes in maternal plasma and their effects on endothelial cell migration. PLoS One 2014, 9:e98667.

8. Atay S, Gercel-Taylor C, Kesimer M, Taylor DD: Morphologic and proteomic characterization of exosomes released by cultured extravillous trophoblast cells. Exp Cell Res 2011, 317:1192-1202.

9. Théry C, Zitvogel L, Amigorena S: Exosomes: Composition, biogenesis and function. Nat Rev Immunol 2002, 2:569-579.

10. Sahoo S, Losordo DW: Exosomes and cardiac repair after myocardial infarction. Circ Res 2014, 114(2):333-344.

11. Aplin JD: Implantation, trophoblast differentiation and haemochorial placentation: mechanistic evidence in vivo and in vitro. J Cell Sci 1991, 99(Pt 4):681-692

12. Mincheva-Nilsson L: Placental exosome-mediated immune protection of the fetus: feeling groovy in a cloud of exosomes. Expert Rev Obstetrics Gynaecol 2010, 5:619-634.

13. Kshirsagar S, Alam S, Jasti S, Hodes H, Nauser T, Gilliam M, Billstrand C, Hunt J, Petroff M: Immunomodulatory molecules are released from the first trimester and term placenta via exosomes. Placenta 2012, 33:982-990.

14. Kobayashi M, Salomon C, Tapia J, Illanes SE, Mitchell MD, Rice GE: Ovarian cancer cell invasiveness is associated with discordant exosomal sequestration of Let-7 miRNA and miR-200. J Trans/ Med 2014, 12:4.

15. Gagnon R: Placental insufficiency and its consequences. Eur J Obstet Gynecol Reprod Biol 2003, 110(Suppl 1):S99-S107.

16. Masoura S, Kalogiannidis IA, Gitas G, Goutsioulis A, Koiou E, Athanasiadis A Vavatsi N: Biomarkers in pre-eclampsia: a novel approach to early detection of the disease. J Obstet Gynaecol J Inst Obstet Gynaecol 2012, 32:609-616

17. Thery C, Amigorena S, Raposo G, Clayton A: Isolation and characterization of exosomes from cell culture supernatants and biological fluids. In Current protocols in cell biology / editorial board, Juan S Bonifacino [et al.]. 2006. Chapter 3:Unit 322.
18. Pap E, Pállinger E, Falus A, Kiss AA, Kittel A, Kovács P, Buzás El: T Lymphocytes are Targets for Platelet- and Trophoblast-Derived Microvesicles During Pregnancy. Placenta 2008, 29:826-832.

19. Dragovic RA, Southcombe JH, Tannetta DS, Redman CW, Sargent IL: Multicolor flow cytometry and nanoparticle tracking analysis of extracellular vesicles in the plasma of normal pregnant and pre-eclamptic women. Biol Reprod 2013, 89:1-12.

20. Salomon C, Sobrevia L, Ashman K, Illanes S, Mitchell MD, Rice GE: The role of placental exosomes in gestational diabetes mellitus. In Gestational Diabetes-Causes, Diagnosis and Treatment. Edited by Sobrevia L. 2013.

21. Ge Q, Zhou Y, Lu J, Bai Y, Xie X, Lu Z: miRNA in plasma exosome is stable under different storage conditions. Molecules 2014, 19:1568-1575.

22. Taylor DD, Gercel-Taylor C: MicroRNA signatures of tumor-derived exosomes as diagnostic biomarkers of ovarian cancer. Gynecol Oncol 2008, 110:13-21.

23. van der Pol E, Böing AN, Harrison P, Sturk A, Nieuwland R: Classification, functions, and clinical relevance of extracellular vesicles. Pharmacol Rev 2012, 64:676-705,

24. Mincheva-Nilsson L, Baranov V: The Role of Placental Exosomes in Reproduction. Am J Reprod Immunol 2010, 63:520-533.

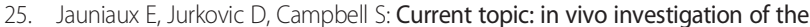
placental circulations by Doppler echography. Placenta 1995, 16:323-331.

26. Valentin L, Sladkevicius P, Laurini R, Soderberg H, Marsal K: Uteroplacental and luteal circulation in normal first-trimester pregnancies: Doppler ultrasonographic and morphologic study. Am J Obstet Gynecol 1996, 174:768-775.

27. Merce LT, Barco MJ, Alcazar JL, Sabatel R, Troyano J: Intervillous and uteroplacental circulation in normal early pregnancy and early pregnancy loss assessed by 3-dimensional power Doppler angiography. Am J Obstet Gynecol 2009, 200:311-318. 315 e.

28. Wortelboer EJ, Koster MP, Kuc S, Eijkemans MJ, Bilardo CM, Schielen PC, Visser GH: Longitudinal trends in fetoplacental biochemical markers, uterine artery pulsatility index and maternal blood pressure during the first trimester of pregnancy. Ultrasound Obstet Gynecol Off J Int Soc Ultrasound Obstet Gynecol 2011, 38:383-388.

29. Sabapatha A, Gercel-Taylor C, Taylor DD: Specific isolation of placenta-derived exosomes from the circulation of pregnant women and their immunoregulatory consequences. Am J Reprod Immunol 2006, 56:345-355.

30. Vongthavaravat V, Nurnberger MM, Balodimos N, Blanchette H, Koff RS Isolated elevation of serum alkaline phosphatase level in an uncomplicated pregnancy: a case report. Am J Obstet Gynecol 2000, 183:505-506.

31. Leitner K, Szlauer R, Ellinger I, Ellinger A, Zimmer KP, Fuchs R: Placental alkaline phosphatase expression at the apical and basal plasma membrane in term villous trophoblasts. J Histochem Cytochem Off J Histochem Soc 2001, 49:1155-1164.

32. Kniss DA, Xie Y, Li Y, Kumar S, Linton EA, Cohen P, Fan-Havard P, Redman $C W$, Sargent IL: $E D(27)$ trophoblast-like cells isolated from first-trimester chorionic villi are genetically identical to HeLa cells yet exhibit a distinct phenotype. Placenta 2002, 23:32-43.

33. Bashiri A, Katz O, Maor E, Sheiner E, Pack I, Mazor M: Positive placental staining for alkaline phosphatase corresponding with extreme elevation of serum alkaline phosphatase during pregnancy. Arch Gynecol Obstet 2007, 275:211-214

34. Hina K, Christopher GA, Michael L, Ching Seng A, Adam M, Richard JS, Mark $\mathrm{DH}$, Suresh M: Comparative proteomics evaluation of plasma exosome isolation techniques and assessment of the stability of exosomes in normal human blood plasma. PROTEOMICS 2013, 13(22):3354-3364

35. Gallo A, Tandon M, Alevizos I, Illei GG: The Majority of MicroRNAs Detectable in Serum and Saliva Is Concentrated in Exosomes. PLoS One 2012, 7:e30679.

36. Tauro BJ, Greening DW, Mathias RA, Ji H, Mathivanan S, Scott AM, Simpson $\mathrm{RJ}$ : Comparison of ultracentrifugation, density gradient separation, and immunoaffinity capture methods for isolating human colon cancer cell line LIM1863-derived exosomes. Methods 2012, 56:293-304.

37. Luo S-S, Ishibashi O, Ishikawa G, Ishikawa T, Katayama A, Mishima T, Takizawa T, Shigihara T, Goto T, Izumi A, Ohkuchi A, Matsubara S, Takeshita T, Takizawa T: Human Villous Trophoblasts Express and Secrete Placenta-Specific MicroRNAs into Maternal Circulation via Exosomes. Biol Reprod 2009, 81:717-729.

38. Simpson RJ, Lim JW, Moritz RL, Mathivanan S: Exosomes: proteomic insights and diagnostic potential. Expert Rev Proteomics 2009, 6:267-283. 
39. Pant S, Hilton H, Burczynski ME: The multifaceted exosome: Biogenesis, role in normal and aberrant cellular function, and frontiers for pharmacological and biomarker opportunities. Biochem Pharmacol 2012, 83:1484-1494

40. Michelle EM, Joshua NL: FedExosomes: Engineering Therapeutic Biological Nanoparticles that Truly Deliver. Pharmaceuticals 2013, 6:659-680.

41. Donker RB, Mouillet JF, Chu T, Hubel CA, Stolz DB, Morelli AE, Sadovsky Y: The expression profile of C19MC microRNAs in primary human trophoblast cells and exosomes. Mol Hum Reprod 2012, 18:417-424.

42. Tannetta DS, Dragovic RA, Gardiner C, Redman CW, Sargent IL: Characterisation of Syncytiotrophoblast Vesicles in Normal Pregnancy and Pre-Eclampsia: Expression of Flt-1 and Endoglin. PLoS One 2013, 8(56764):1-12.

\section{doi:10.1186/1479-5876-12-204}

Cite this article as: Sarker et al:: Placenta-derived exosomes continuously increase in maternal circulation over the first trimester of pregnancy. Journal of Translational Medicine 2014 12:204.

\section{Submit your next manuscript to BioMed Central and take full advantage of:}

- Convenient online submission

- Thorough peer review

- No space constraints or color figure charges

- Immediate publication on acceptance

- Inclusion in PubMed, CAS, Scopus and Google Scholar

- Research which is freely available for redistribution 